\title{
THE PATENT PARADOX REVISITED: DETERMINANTS OF PATENTING IN THE US SEMICONDUCTOR INDUSTRY, 1980-94
}

Bronwyn H. Hall

Rose Marie Ham

Working Paper 7062

http://www.nber.org/papers/w7062

\author{
NATIONAL BUREAU OF ECONOMIC RESEARCH \\ 1050 Massachusetts Avenue \\ Cambridge, MA 02138 \\ March 1999
}

\begin{abstract}
Revised version of a paper prepared for presentation at the January 1999 NBER "Patent System and Innovation" conference in Santa Barbara, California, sponsored by the Alfred P. Sloan via a grant to the NBER Project on Industrial Technology and Productivity. We are indebted to numerous industry representatives and patent attorneys for their participation in this study, to Jerry Karls of Integrated Circuit Engineering, Inc., for sharing industry data, and to Jeff Macher, Haas School of Business, for participating in interviews with design firms. We also thank Melissa Appleyard, Wes Cohen, David Hodges (co-director of the UC Berkeley Competitive Semiconductor Manufacturing Program), Adam Jaffe, Jenny Lanjouw, Josh Lerner, Rob Merges, David Mowery, Cecil Quillen, and participants in the Berkeley Innovation Seminar, Berkeley IDS 270 Seminar, and the Santa Barbara conference for their insights and suggestions. The views expressed in this paper are those of the authors and do not reflect those of the National Bureau of Economic Research.
\end{abstract}

- 1999 by Bronwyn H. Hall and Rose Marie Ham. All rights reserved. Short sections of text, not to exceed two paragraphs, may be quoted without explicit permission provided that full credit, including ${ }^{\bullet}$ notice, is given to the source. 
The Patent Paradox Revisited: Determinants

of Patenting in the US Semiconductor Industry, 1980-94

Bronwyn H. Hall and Rose Marie Ham

NBER Working Paper No. 7062

March 1999

\begin{abstract}
$\underline{\text { ABSTRACT }}$
This paper examines the patenting behavior of firms in an industry characterized by rapid technological change and cumulative innovation. Recent evidence suggests that semiconductor firms do not rely heavily on patents, despite the strengthening of US patent rights in the early 1980s. Yet the propensity of semiconductor firms to patent has risen dramatically over the past decade. This paper explores this apparent paradox by analyzing the patenting activities of almost 100 US semiconductor firms during 1980-94. The results suggest that stronger patents may have facilitated entry by firms in niche product markets, while spawning "patent portfolio races" among capital-intensive firms.
\end{abstract}

Bronwyn H. Hall

Department of Economics

549 Evans Hall \#3880

University of California, Berkeley

Berkeley, CA 94720-3880

and NBER

bhhall@econ.berkeley.edu
Rose Marie Ham

Haas School of Business

University of California, Berkeley

Berkeley, CA 94720 


\section{Introduction}

Fundamental changes in the US legal environment during the past 15 years have reshaped how firms protect and enforce their intellectual property rights. Most notable among these changes was the 1982 formation of a centralized appellate court, the Court of Appeals for the Federal Circuit, which ushered in a "pro-patent" legal environment in the United States. Despite this strengthening of US patent rights and a perceived increased importance of patents, recent survey evidence suggests that US manufacturing firms in most industries rely more heavily on secrecy and lead time to recoup their $R \& D$ investments than they do on legal mechanisms such as patents and that, if anything, the effectiveness of patents as a means of appropriating $R \& D$ returns has declined since the early 1980s (Cohen et al. 1997). ${ }^{1}$ Even more surprising, this reported decline in the effectiveness of patents has coincided with a recent and unprecedented surge in the overall number of US patents applied for and granted to firms each year (Kortum and Lerner 1997).

This paper examines this "patent paradox" more closely by exploring the role of patents in the semiconductor industry, where the gap between the relative ineffectiveness of patents (as reported in surveys) and their widespread use is particularly striking. For example, semiconductor firms reported a below-average level of effectiveness for patents in the 1994 "Carnegie-Mellon survey" (Cohen et al. 1997) and, in fact, appear to rely much more heavily on secrecy than they did in the influential "Yale appropriability survey" conducted in 1983 (Levin et al. 1987). ${ }^{2}$ At the same time, the past decade has witnessed a surge in the number of US patents involving semiconductor technologies, surpassing the overall increase in US patenting during this period reported by Kortum and Lerner (1997). ${ }^{3}$ The propensity of semiconductor firms to patent has likewise risen dramatically over this period: patenting per million 1992 real R\&D dollars in the semiconductor industry doubled between 1982 and 1992, from about 0.3 to 0.6. During the same period, the patent yield for manufacturing as a whole was fairly stagnant and that for pharmaceuticals actually declined (see Figure 1). ${ }^{4}$

The purpose of this paper is to address a simple question: If semiconductor firms do not rely heavily on patents to recoup their R\&D investments (as they have claimed in prior surveys), then why are these firms patenting so aggressively? The semiconductor industry provides an excellent setting within which to examine the effects of stronger patent rights on firms engaged in “cumulative systems" technologies (Scotchmer 1991; Merges and Nelson 1990; Merges 1996). Much like multimedia or computer firms, semiconductor firms often require access to a "thicket" of intellectual property rights owned by a diverse set of entities in order to advance the technology 
or simply to produce their products (Merges 1996). Because the pace of technology is rapid and numerous industry participants exist, any new product or process will often overlap with technologies developed, either in parallel or in the past, by an array of external parties (Grindley and Teece 1997). As such, we also hope to shed light on more fundamental, but difficult questions: what are the effects of stronger patent rights in industries characterized by cumulative innovation, rapid change, and multiple owners of overlapping technology rights? Does strengthening the patent system in such industries promote innovation or hinder it?

Our study consists of two complementary research components. First, in order to understand the factors that underpin a firm's decision to patent and how these might differ across firms in this industry, we met with patent managers and executives from several types of semiconductor firms, including large manufacturers and smaller firms that have entered the industry during the past decade. We used these interviews to explore issues that are difficult to track with publicly available sources (e.g., changes in internal management practices or an increased reliance on trade secrets) and to understand the technological and contractual environment within which these firms operate. Although the interviews are not necessarily representative of industry-wide practices, they capture a cross-section of views on the role of patents, their use, and their perceived effects on innovation in this industry that enable us to unravel the somewhat perplexing findings of recent studies in this field.

Drawing on the insights gained from these interviews, the second part of our study analyzes the patent strategies of a much larger set of semiconductor firms over a twenty year period, or before and after the strengthening of US patent rights took place. We first identify the universe of approximately 100 publicly-traded, US firms whose principal line of business is semiconductors and related devices (SIC3674) and whose R\&D expenditures are therefore primarily directed towards semiconductor-related areas. We then compile a detailed database of these firms' patent portfolios from 1975 to 1996 and match these data with other financial variables from Compustat (e.g., R\&D, sales, and capital expenditures) that are known determinants of patenting in general ${ }^{5}$ and that capture key variables identified in our interviews.

There are several advantages of this approach. First, unlike recent studies, we are able to construct reliable estimates of changes in the patent propensities of these firms over this twentyyear period while keeping the broad technological area constant across firms. ${ }^{6}$ Second, we are able to examine whether the patterns we observe are simply driven by a change in the mix of firms in the industry over time (i.e., the effects of entry and exit). The main drawback of our approach is 
that we exclude large "systems" manufacturers (such as IBM, AT\&T or Motorola, and non-US firms such as Toshiba or Samsung) that are important patent owners and users of semiconductor technologies, but for which we lack reliable estimates of R\&D investment targeted at semiconductor technologies.

Our results demonstrate that US semiconductor firms are indeed patenting aggressively: not only has their overall propensity to patent increased dramatically during the "pro-patent" era, but this increase far exceeds that of US manufacturers as a whole. Our interviews suggest that these "patent portfolio races" are quite different from the models envisioned by the classic "patent

${ }^{7}$ Instead of being driven by a desire to win strong legal rights to a standalone technological prize, these firms are driven by broader motives: with large sunk costs in manufacturing facilities and a need to draw on process and product technologies invented (and patented) by a diverse array of parties, manufacturers amass large patent portfolios of their own, largely to avoid being excluded or "held up" by other parties. Although patents still perform their traditional function of safeguarding against outright theft and infringement of these firms' inventions, this classical role of patents seems to be dominated by a broader use of patents as "legal bargaining chips" that enable the firms to avoid being excluded in a particular field of use, to obtain more favorable terms to their licensing agreements, to safeguard against costly patent litigation, or to gain access to external technologies on more favorable terms of trade. ${ }^{8}$ Although the "strategic" use of patents has been widely noted (e.g., Cohen et al. 1997; Parr and Sullivan, 1996) and clearly demonstrated in other accounts of the semiconductor and electronics industries (Grindley and Teece 1997), the broader prevalence of such behavior and the extent to which it has increased during the "pro-patent" era in the United States have not yet been empirically examined. Our analysis represents an important step in that direction.

Our results also suggest that firms that entered the industry after 1982 appear to patent more aggressively than pre-1982 entrant firms, relative to what we would expect based on their size and R\&D spending. Our interviews suggest that stronger patent rights were important to these firms (about half of which are design firms, specializing in product innovation) in attracting venture capital funds and securing proprietary rights in niche product markets; it is less clear that ownership of strong patent rights was important to these firms in licensing their technologies or in managing their vertical relationships with suppliers of manufacturing services. ${ }^{9}$ These results contrast with those of other studies where entrant firms are shown to rely more heavily on trade 
secrecy and therefore "opt out" of the patent systems because of their relative disadvantage in asserting and defending those rights in court (Lerner 1994, 1995; Lanjouw 1994).

The paper is organized as follows. In the next section, we briefly lay out the institutional shift that took place in the United States during the early 1980s and discuss previous empirical studies that examine its effects. We focus on three main hypotheses generated by Kortum and Lerner (1997) that are central to our analysis. We then draw on recent theoretical literature to refine the hypotheses in ways that better reflect the contractual dilemmas posed by strengthening patent rights in an industry characterized by rapid technological change, cumulative innovation, and overlapping property rights. In Section 3, we discuss the results from our field interviews that shed light on the changing incentives to patent and that highlight differences among firms. Section 4 contains the empirical analysis, describes the data we constructed, and explains the methods we used. We also discuss our econometric results in this section. In Section 5, we explore alternative hypotheses and identify next steps in our research. Section 6 concludes.

\section{The Strengthening of US Patent Rights and Its Effects}

The patent system has long been recognized as an important policy instrument used to promote innovation and technological progress. Two fundamental mechanisms underpin the patent system. First, an inventor discloses to the public a "novel", "useful", and "non-obvious" invention. In return, the inventor receives the right to exclude others from using that invention for a fixed period of time (now 20 years from the date of patent application in the United States). The rules of the patent game may differ from country to country (e.g., whether rights are assigned to the first inventor or the first to file the patent application), but the underlying principle remains the same. By providing exclusionary rights for some period of time and a more conducive environment in which to recoup $R \& D$ investments, the patent system aims to encourage inventors to direct more of their resources toward R\&D than would otherwise be the case. At the same time, detailed information about the invention is disclosed to the public when the patent application is published.

Although governmental agencies (in the United States, the US Patent and Trademark Office) examine applications and decide whether an invention qualifies for patent protection, the courts ultimately determine the strength of patent rights once granted. By deciding whether a patent is valid or whether another party has infringed on the patent owner's rights, courts play a pivotal role in determining the strength (and hence, the value) of patent rights. Patent rights alone may be 
insufficient to enable the inventor to profit from the invention, but stronger patent rights may tilt the scale in favor of patent owners.

\subsection{The "Pro-Patent" shift in the US Legal Environment}

Several important changes took place in the US legal environment during the early 1980s that collectively strengthened the rights conferred on US patent owners, regardless of whether these owners were independent inventors, universities, or firms. The pendulum started to swing in 1980, when the US Supreme Court reversed its stance on the patent-antitrust interface and endorsed exclusive, strong patent rights in promoting innovation and investment. ${ }^{10}$ The renewed faith in intellectual property rights was echoed in legislative initiatives in the early 1980s, a period during which US firms faced increased competition from foreign firms, many of whom had improved their abilities to exploit advances made in U.S. R\&D laboratories. First, the Bayh-Dole Act of 1980 eased restrictions on federal agencies when granting licenses to small businesses and non-profits for patents based on federally-funded research. Second, antitrust laws were relaxed in 1984 in hopes of encouraging firms to cooperate with one another in "pre-commercial" research projects. ${ }^{11}$ A third legislative initiative was specifically aimed at improving the ability of semiconductor firms to prevent unauthorized copying and use of their semiconductor layout designs. More specifically, the Semiconductor Chip Protection Act of 1984 created a new sui generis form of intellectual property rights (conceptually similar to copyright) for the layout, or "mask work", of semiconductors. $^{12}$

No other event solidified this "pro-patent" shift in the United States more than the 1982 creation of the Court of Appeals for the Federal Circuit (CAFC), a specialized appellate court with jurisdiction over patent cases. ${ }^{13}$ The driving force behind the creation of the CAFC was a lack of uniformity among US courts in interpreting the patent statute. ${ }^{14}$ In addition to unifying US patent doctrine, the CAFC established a number of procedural and substantive rules that strengthened the enforceability of patent rights (Merges 1997; Lerner 1995; Taylor and Higgins 1994). For example, the court made it more difficult to challenge a patent's validity ${ }^{15}$ was more willing to grant an injunction against an infringer (Lanjouw and Lerner 1996), and increased the penalties on infringers by awarding higher damages in patent disputes (Merges 1997; Kortum and Lerner 1997). Plaintiff success rates in patent infringement suits also increased substantially during this period (Lerner 1995). ${ }^{16}$ 


\subsection{The effects of strong patent rights revisited.}

The effects of stronger patent rights on the intensity with which firms patent remains unclear. ${ }^{17}$ To the extent that stronger patent rights enable firms to recoup more of their R\&D dollars, stronger patent rights should increase incentives to invest in R\&D. ${ }^{18}$ In this scenario, there is little reason to suspect that these increased $R \& D$ dollars should yield proportionally more patents. Thus, unless other changes in the R\&D process itself occur (such as a shift toward more "applied," patentable activities or improvements in research methods that speed or ease the inventive process), stronger patent rights should not generate an increase in the numbers of patents generated per R\&D dollar.

A longstanding literature in the innovation and economics literatures has established, however, that the effectiveness of patents varies greatly across industries and technological areas (Scherer 1959; Taylor and Silberston 1973; Mansfield 1986), and that firms in only a handful of industries, such as pharmaceuticals and chemicals, rely heavily on patents to recoup their R\&D investments (Levin et al. 1987). ${ }^{19}$ Thus we might expect that the simple argument elucidated above does not always apply, since the primary motivation for patenting in many industries may not be directly related to protecting investments in $\mathrm{R} \& \mathrm{D}$. For example, some studies suggest that stronger patent rights have simply enabled firms with large legal departments to extract rents from and deter entry by other firms in the industry. Lerner (1994) shows that small firms are far more likely to "opt out" of the patent system entirely and rely more heavily on formal trade secret mechanisms to protect their inventions. In another study, Lerner (1995) shows that new biotechnology firms "avoid the shadows" of competitors, but by patenting in areas that are not already occupied by firms better-positioned to enforce their patent rights in court. In a similar vein, Lanjouw (1994) finds that the value associated with patents also differs across firms, simply because of the "true" value of patents are often not revealed until such rights are held valid by the courts, a process that places a disproportionate burden on poorly capitalized firms.

The findings of two recent studies are especially important for the arguments in this paper. Kortum and Lerner (1997) explore whether the strengthening of US patent rights in the early 1980s led to the unprecedented surge in US patenting over the past decade. They identify four possible causes and reject all but the last using evidence on worldwide patenting in many technologies:

- The "friendly court" hypothesis, which would imply a rush to patent in the United States versus other countries that has not occurred. 
- The "regulatory capture" hypothesis, which implies that incumbent large firms should be leading the surge.

- The "fertile technology" hypothesis, which implies that the increase in patenting should be concentrated in certain technology classes such as biotechnology and software.

- $\quad$ Changes in the management of R\&D that lead to increases in R\&D productivity (e.g., in biotech, see Arora and Gambardella 1994) and a shift to more applied activities has increased the yield of patentable discoveries.

Based on our interviews, we would modify the conclusions of Kortum and Lerner in two ways: first, it is clear from talking to semiconductor firms that regulatory capture (implying a more aggressive use of intellectual property rights by large firms with deep pockets) could easily cause a strategic response among non-patenting small and medium-sized firms and entrants as they attempt to negotiate licensing or cross-licensing agreements on more favorable terms. If this is true, regulatory capture does not necessarily imply that large incumbent firms will have a greater incentive to patent than new entrants to the industry.

Second, we consider changes in the "management of R\&D" more broadly. Even with no change to the strategy and goals of their R\&D programs, it was clear from our conversations that many firms had decided to "harvest" more patents from their R\&D, both as a defensive strategy and to assist them in winning favorable terms in cross-licensing negotiations with other firms in the industry. ${ }^{20}$ Thus we agree that the increase in patenting in the semiconductor industry arises partly from a shift in the management of $R \& D$, but we do not believe that the shift is solely explained by a move toward more applied R\&D. Instead, our interviews suggest that many firms in this industry increased their propensity to patent in response to an increasing threat of "hold-up" when they are sued for infringement. The threat has increased because patents are more likely to be upheld and because the nature of innovation in this industry has become more complex and depends on technological inputs from more actors.

A second relevant study is the Carnegie-Mellon Survey of Industrial R\&D in the United States (Cohen, Nelson, and Walsh 1996, 1997). This survey found that patents were a relatively ineffectual mechanism by which firms in the semiconductor industry recoup R\&D investments (both in absolute terms and relative to firms in other industries) and that firms now rely more heavily on secrecy than they did in the early 1980s. Based on a sample of 14 responses in the 
"semiconductor and related equipment" industry, Cohen et al. (1996) report that the ranking of appropriability mechanisms for product innovation in decreasing order of importance is 1) product complexity; 2) secrecy; 3) lead time; 4) complementary sales and service; 5) complementary manufacturing; with patents and other legal means a distant sixth and seventh. ${ }^{21}$ The ranking for process innovations was similar, although patents were found to be even less effective for this kind of innovation.

A somewhat smaller sample of respondents (11) in this industry answered a series of questions about the reasons for patenting in their industry. ${ }^{22}$ The most important reasons for patenting product innovations were to prevent copying and to block another firm patenting a related innovation, followed by use in negotiations and prevention of infringement suits. Except for copying, these reasons are consistent with what our interviewees told us. For process patents, the ranking was similar, although use in negotiations was somewhat less important.

The Carnegie-Mellon results confirm that in many industries, the prevention of imitation is only one of several reasons for patenting. Although the authors note that the broader use of patents may be especially important in industries where innovation is incremental (and where the value of a single patents is inherently tied to the value of other patented and unpatented developments), they do not examine these effects explicitly. They summarize their results as follows:

"The picture that emerges from our results is that the prevention of imitation is only one of several reasons for patenting. The motive of blocking as well as the prominent motives of the prevention of suits and use in negotiations suggest that patents are used more broadly than simply to protect the returns to a specific innovation." (Cohen et al. 1997: p. 17).

Summing up the results of this recent research on the motives for patenting, some questions still remain: if firms rely more heavily on trade secrecy and lead time to profit from innovation, then why do they patent so aggressively? Have firms redirected more of their research portfolios toward applied projects or improved their management of the innovation process (Kortum and Lerner 1998)? Or, have patents simply become more important "bargaining chips" to firms in their efforts to craft favorable licensing deals and to keep potential litigants at bay (Cohen et al. 1997)? And how does the use of patents vary among firms in the same industry?

\section{Field Interviews}

In order to illuminate the factors that have influenced semiconductor firms' increased propensity to patent and the effect, if any, of the "pro-patent" shift on different types of firms, we 
first met with patent managers and executives from two types of semiconductor firms: ${ }^{23}$ (1) incumbent firms and (2) firms that entered the semiconductor industry since 1982, after the shift to a "pro-patent" environment. As shown in Table A.2, the sample includes large and medium-sized semiconductor manufacturers, who are engaged in both process and product innovation, as well as smaller design firms, who are engaged primarily in product innovation. ${ }^{24}$ Only one of the firms, Texas Instruments, held a large patent portfolio (both in absolute terms and relative to its R\&D spending) prior to the shift in US patent policies. $^{25}$

\subsection{Patents as an appropriability mechanism}

Are patents important to firms in the semiconductor industry? In general, the answer to this question was “yes, patents are extremely important." But the reasons for their importance often had little to do with whether patents provide an incentive to conduct R\&D or enable the firm to profit from the current-generation products. As one interviewee noted, "semiconductor firms do not rely on patents [to profit from innovation or appropriate returns from $R \& D$ ], but patent rights are still of critical importance to firms in this industry."

Consistent with the findings of the Carnegie Mellon survey and earlier studies on how firms profit from innovation in the semiconductor and other industries ${ }^{26}$, interviewees noted that semiconductor firms generally rely on mechanisms other than patents to profit from innovation. Because of the short product life cycles in this industry and the fact that competitive advantage is largely driven by lead time, design complexity, and (for manufacturers) superior manufacturing capabilities, patents are a relatively ineffective means by which to profit from inventions-at least for current-generation products. For example, it takes 18 months on average for a patent to issue in the United States, while the average life cycle of semiconductor products ranges from a year to 16 months. Occasionally, successor generations of products will incorporate the older technology embodied in the patent, but even this period might last 4-6 years, which is far less than the 20 year life of the patent. As we note below, however, the longer-term value of these patents can be quite high if future generations of products build on the patented technology, this technology becomes widely used by other firms, and alternative methods are difficult or prohibitively costly to adopt. ${ }^{27}$

Interviewees highlighted another aspect of patenting in semiconductor technologies that affects the ability of patents to exclude competitors. Unlike many biotechnology or pharmaceutical products, for example, a given semiconductor product (say, a new ethernet card or a memory device) will likely be covered by hundreds if not thousands of individual patents that cover aspects of the circuitry design, materials used to achieve a certain outcome, and the broad array of methods 
used to manufacture the device. It is difficult, therefore, for firms to rely on a single patent or set of patents to entirely exclude rivals from a given product line. Interviewees noted that although firms can and often do obtain webs of related patents surrounding critical technologies, a single patent is generally far less critical to a product's success than is true in biotechnology or pharmaceuticals.

The maze of patents embodied in a typical semiconductor product was also identified as one of the reasons that patents are especially valuable to semiconductor firms as "bargaining chips." A single firm rarely owns all the rights (either based on its own patents or licensing agreements) to technologies embodied in a new product; as such, it is important to have assets with which to trade in the event that other patent owners assert their rights against the firm. Because of the complexity of semiconductor manufacturing, the diverse range of technologies employed in the wafer fabrication process and the rapid depreciation of high-volume fabs, firms that operate and own state-of-the-art manufacturing facilities (fabs) appear to face a greater need to bargain with other holders of patent rights than is true of design firms, which tend to specialize in product innovation.

Ironically, the rapid pace of technological change and short product life cycles that characterize the semiconductor industry appear to increase rather than diminish these firms' incentives to patent. If product life cycles were longer, firms would need to think more carefully about whether competitors could benefit from the information disclosed in the patent application and would perhaps protect a broader range of inventions with trade secrecy instead. As one executive noted, "If we relied on patents for technical information, we would quickly go out of business." Thus, on the one hand, short product life cycles tend to undermine the ability of firms in this industry to rely exclusively on patents to profit from inventions on a given generation of products. On the other hand, because patent rights extend across generations of products and technologies and invention in this field is highly cumulative, patents may nonetheless be valuable in negotiations with other patent owners. Within this context, the rapid product life cycles that characterize this industry may contribute to an aggressive patenting strategy: by obtaining a patent, the firm purchases an option to exclude others from using its patented invention (a potentially valuable asset in negotiations with other patent owners or with users of the technology), while ensuring the firm's "freedom to design and manufacture" products using technologies that it developed. At the same time, the firm is able to secure this legal right to exclude without disclosing information that would jeopardize the firm's competitive advantage.

\subsection{Changing incentives to patent?}


Without exception, interviewees emphasized that the stronger patent rights ushered in by the Court of Appeals for the Federal Circuit (CAFC) reshaped the incentives of semiconductor firms to invest in US patent rights. But the implications of the "pro-patent" shift appeared to differ among the types of firms in the interview sample, depending on the size and strength of their patent portfolios in the early 1980s, the extent to which other patent owners could credibly threaten to exclude the firm from using critical technologies or could extract royalties for use of such technologies, and somewhat related, whether the firm owns and operates complex manufacturing facilities or specializes in product design. Despite the small number of firms in the interview sample, questions about the perceived effects of the early-1980s shift in US patent policies generated a rich set of general findings. Here, we focus on differences among manufacturers and design firms, most of which entered the industry during the era of stronger US patent rights.

\subsubsection{Large-scale manufacturers: the increased value of patents as bargaining chips}

Most of the interviewees from firms operating large-scale manufacturing facilities emphasized that the formation of the CAFC altered the "rules of the patent game" and increased their incentives to patent. On the one hand, stronger patent rights increased the ability of some firms (such as Texas Instruments) to secure income from licensing rights to patents on more favorable terms. Indeed, interviewees were well aware of the strategies that Texas Instruments had put in place to manage and to profit from its patent portfolio and representatives from several manufacturers expected to employ similar strategies as their patent portfolios grew larger. A more common response among manufacturers, however, was a need to respond to the increased exclusionary power of other patent owners by investing in patents of their own to use in licensing or cross-licensing negotiations.

Two events, both related to the change in US patent policies, were frequently mentioned as important in redirecting the patent strategies of several manufacturers in our sample. First, numerous interviewees emphasized the importance of Polaroid's successful patent infringement suit against Kodak; in 1986, Polaroid was awarded almost $\$ 1$ billion in damages and Kodak was barred from competing in the instant-film camera business. ${ }^{28}$ The large penalties imposed in this case and the realization that US courts were willing to take an aggressive stance against infringement by halting — either temporarily or permanently_production based on infringing technologies fueled concerns among executives in many firms, including semiconductor manufacturers. As one interviewee noted, "a preliminary injunction would be detrimental to a firm if it means shutting down a high-volume manufacturing facility; loss of one week's production 
alone can cost in the millions of dollars." The licensing director of another manufacturer noted that the threat of injunction is indeed a powerful lever against firms in negotiating royalty rates.

The second widely cited reason for the surge in patenting by semiconductor manufacturers was referred to by some as a "Texas Instruments" effect. ${ }^{29}$ Beginning around 1985-6, Texas Instruments successfully asserted its patents in court for a range of inventions pertaining to integrated circuits (e.g., the "Kilby patent" on the basic design of the integrated circuit) and manufacturing methods (e.g., the method for encapsulating chips or transporting wafers from one manufacturing platform to another). Although the original suits were against non-US firms, the success of TI's patents in court enabled the firm to earn higher royalty payments from other firms in the industry. Others noted that AT\&T, IBM, and Motorola also began asserting their patent rights more aggressively during the 1980s in an attempt to earn increased royalties based on their large portfolios of semiconductor-related inventions. According to several industry representatives, these large patent owners increased their charges for rights to infringe their patents during this period and more actively sought royalty payments from smaller firms. ${ }^{30}$

According to interviewees from several large manufactures (excluding TI), patents became more important to their firms during this "pro-patent" environment to use as bargaining chips in negotiations with other patent owners. Some noted that the semiconductor industry has historically been characterized by broad, cross-licensing of patent rights among manufacturers and that, to a large extent, this is still the case. Nonetheless, if a firm lacks a strong patent portfolio of its own with which to negotiate licensing or cross-licensing agreements, its profits could be eroded quickly by the outflow of royalty payments to a disparate array of owners of semiconductor-related patent rights. ${ }^{31}$ In response, several interviewees described what appears to be a "race to patent" by their firms - not a race to win rights to some standalone technological prize, but a race to secure the right to exclude others before being excluded themselves. This is not to say that patents do not serve some of their traditional function of safeguarding against outright theft of patented ideas. But rather, this traditional reason for obtaining patents for several of these manufacturers appeared to be dwarfed by broader motives. ${ }^{32}$

Regardless of the underlying motive, several of the manufacturers in our sample were clearly "ramping up" their patent portfolios and "harvesting" their "latent inventions" to add to their stock of issued patents. For example, one firm had "shifted from owning a total of 30 patents [in 1990] to filing over 300 patents in one year" with an internal goal in place to "own 1000 patents by the year 2000." Another manufacture had set an even more ambitious " 1000 by 2000" 
patent goal while maintaining a relatively stable R\&D budget: before 1993, the firm typically filed 100 patent applications per year (which rose to 650 patent applications in 1996 to a goal of 1000 applications filed in a single year by 2000). The increased volume of patent filings appeared to reflect a "deeper reach" into an existing pool of inventions rather than a shift in R\&D activities per se. As one interviewee noted, there were "a lot of patentable inventions sitting around," but the firm had simply "not taken the time and incurred the cost" to patent these inventions in the past.

\subsubsection{Design firms: securing rights in niche product markets?}

The "bargaining chip" role of patents was less prominent in our interviews with the firms specializing in semiconductor product design. The two highly profitable design firms in our interview sample had established sophisticated in-house patent committees and were patenting aggressively in their core product lines. Unlike manufacturers, these firms appeared to be driven by a desire to secure broad proprietary rights to technologies in niche product markets. Although one firm was starting to patent for defensive reasons (i.e., in anticipation of future requests from larger firms for royalty payments), patents were mainly used to improve these firms' competitive position against other niche market rivals. The small number of design firms in our interview sample negotiated surprisingly few licensing agreements involving the sale of rights to infringe their patented technologies or the acquisition of such rights from others. Put differently, patent rights appeared to be more important to these firms for "horizontal" reasons (to gain market share from rival firms) than for "vertical" reasons, such as exchanging know-how or technology with either suppliers of their manufacturing services or customers (Arora and Fosfuri 1998; Arora 1995). The primary "vertical" role of patenting for this small group of firms appeared to be in securing capital from private investors in the start-up phase..$^{33}$

The overall picture that emerged from the interviews was the importance of patents as an imperfect but quantifiable measure of technology that enabled technology-based trades to be made in external markets, both in financial markets (venture capital) and with suppliers and owners of complementary technologies. Although the sample underpinning these interviews is not necessarily representative of the industry as a whole, the general insights suggest that the shift in patent policies in the early 1980s increased the incentives of firms in this industry to patent (with notable exceptions), albeit for reasons that go beyond those traditionally associated with the patent system and that differ among types of firms.

\section{Empirical Analysis}


Our empirical study pursues several lines of inquiry. We first establish whether the increasing patent propensities of firms in this industry simply reflect more general trends observed in other industries. We reject this view, and find that the patent yield in this industry exhibits a rather unique pattern since the mid-1980s.

What, then, explains this apparent shift in the determinants of patenting in the semiconductor industry? We investigate two main hypotheses. The first hypothesis, which we call "strategic response," stems from the contractual view of property rights that argues that stronger patents (and the exclusionary rights that such patents entail) will increase the incentives of firms to patent for reasons other than the traditional incentives provided by the patent system (Merges and Nelson 1990; Cohen et al. 1998; Mazzoleni and Nelson 1997). These incentives are particularly salient in an industry such as semiconductors where the legal rights to semiconductor technologies are distributed across a diverse array of actors, with each holding important but overlapping pieces of technologies that they all need. Under such conditions, a firm has an added incentive to obtain patents simply as "bargaining chips" in negotiations with other patent owners, in gaining access to needed technologies, or in safeguarding against threats of costly litigation. Because of the nature of semiconductor manufacturing and the "thicket" of patents that surrounds semiconductor process technologies, we expect that firms investing heavily in state-of-the-art manufacturing facilities (i.e., firms with high capital intensity, as defined below) will be driven by such concerns more than the firms specializing in product design.

Our second hypotheses, "specialization," stems from the view that stronger patent rights have facilitated a "market for know-how exchange" (Merges 1998; Arora 1995; Arora and Fosfuri 1998). If true, we should find that post-1982 entrant firms (i.e., ones that entered the industry during the "pro-patent" era) rely more heavily on patent protection, controlling for other factors such as their size, R\&D spending, and age.

\subsection{Sample Selection and Data}

The econometric part of this study is based on the universe of 110 publicly traded U.S. owned firms whose principal line of business is in SIC 3674 (semiconductors and related devices) and who have data on Compustat between 1975 and 1996. Because the purpose of this study is to examine changes in the patenting propensities of semiconductor firms over time, we needed reliable indicators for both the patented output of semiconductor firms and the semiconductor-related R\&D investments (inputs) of these firms. Corporate $R \& D$ spending is reported for a firm's entire 
portfolio of research activities, so we restricted our sample to firms whose R\&D investments are primarily directed toward technologies aimed at semiconductor-related products. ${ }^{34}$ After restricting the sample to 1976-1996, dropping duplicate observations and partially-owned subsidiaries, and excluding firms that had less than 3 years of data, we obtained a sample of 97 firms in an unbalanced panel. The 11 omitted firms were primarily small post-1994 startups for which we had inadequate data. The sample used for estimation was further restricted to include data only after 1980 (in order to focus on the changes after the creation of the CAFC) and before 1995 (because of the truncation of the patent data after that date due to lags in the granting of patents). The final sample includes 679 observations on 72 firms between 1980 and 1994.

A major challenge in any study that examines the patenting activities of firms over time is identifying which patents are, in fact, owned by a given firm. ${ }^{35}$ Firms patent under a variety of names (their own and those of their subsidiaries) and the Patent Office does not keep a unique identifier for the same patenting entity from year to year. To construct the entity-level patent portfolios of the firms in our study, we first retrieved the patent portfolios of the firms included in the Case Western patent database (discussed in Hall et al. 1998). This database contains the results of a match between the names of approximately 3,000 manufacturing firms on the Compustat files to about 30,000 of their subsidiaries (using a 1989 "Who Owns Whom" directory).

Because many of the firms in our study are small and entered the industry since 1989, they were not included in the Case Western database. Our analysis also extends into the mid-1990s, and significant mergers and acquisitions have taken place in this industry since 1989 . We therefore constructed updated entity-level portfolios for the firms in our study by identifying name changes, subsidiaries, and mergers and acquisitions from a variety of sources. ${ }^{36}$ These searches generated a total of 14,365 patents issued to these 97 firms during 1975-1996, for an average of 148 total patents per firm. In contrast, 228 patents were issued to the 11 omitted firms from 1975-1996, an average of 21 total patents per firm.

After compiling these entity-level patent portfolios, we retrieved these firms' detailed balance sheet and income statement data from Compustat. The resulting "matched" database combines, for all 97 firms, the front page patent information for their patents that issued during 1975-1996 (e.g., the patent class, when the patent application was filed, the date the patent was issued) with the information contained in Compustat (e.g., annual R\&D spending, capital expenditures, and sales). In addition, we used business directories and industry sources to identify the founding date of each firm (which may precede the date for which we have data by many 
years), and to determine whether the firm owned and operated its own fab (manufacturer) or specialized in product design alone (design firm). ${ }^{37}$

Table 1 gives some summary statistics for our key variables; the top panel is for our universe of firms from 1965 to 1997 and the bottom panel is based on the sample we use for estimation. The median firm in our sample is 27 years old, has approximately 500 employees, does \$5.6 million dollars of R\&D (1992\$), and successfully applies for one patent a year. ${ }^{38}$ However, the distribution of these variables is quite skewed, with over 500 patent applications in one year for one firm (Texas Instruments in 1994) and over one billion dollars of R\&D (Intel in 1994). Design firms represent 11 percent of the observations, and 42 percent have no successful patent applications in a given year. A small number of observations are missing $R \& D$ in one or more years, although all the firms in our sample report R\&D in at least some years. To a great extent, the firms dropped in our cleaning process were younger (often because they actually entered in 1994 or later), smaller, and more likely to be design firms.

\subsection{General Trends}

Figure 1 shows the total patent yield for the 110 firms in our sample, together with the patent yield for all the firms in the Compustat manufacturing sector (firms whose principal SIC is between 2000 and 3999) and for firms in the other computing and electronics industries for comparison. ${ }^{39}$ It is clear from this graph that something changed around 1986 that caused a rather steep rise in the patent applications obtained per million dollars of real $R \& D$ spending in the semiconductor industry; note that although the computing sector exhibits a similar rise, it is much smaller, and the pharmaceutical/biotechnology industry actually shows a decline in the patentR\&D ratio. ${ }^{40}$ Figure 2 shows the number of firms in our estimation sample, which rises smoothly from 24 at the beginning of the period to 72 in 1994. Design firms represent a fair fraction of entrants, of which there are 19 by the end of the period.

In Figure 3, we show the same graph as Figure 1, separated into manufacturing and design (or "fabless") firms. The trend is similar, but design firms seem to have lower patent yields on average and the yield does not rise as steeply. We might expect that firms whose R\&D is focused on product rather than process would have a higher rather than a lower propensity to patent. However, if there are fixed costs of patenting, the smaller design firms may find fewer patents are worth filing for, other things equal. And, as we have already suggested, if firms file for patents partly to avoid having production held up because of an intellectual property dispute, then 
manufacturing firms would have a stronger incentive to file than design firms. We will explore this question later when we estimate equations that describe the propensity of firms to file for patents.

\subsection{Estimating the patent production function}

To explore the determinants of patenting in these semiconductor firms and how they have changed in the past one or two decades, we use a patent production function first introduced by Pakes and Griliches (1980); our specific econometric model was first applied to patent data by Hausman, Hall, and Griliches (1984). The patent production function relates the number of successful patent applications made by a firm in a given year to its past history of R\&D spending, along with other firm characteristics such as size.

Because the number of successful patent applications made by a semiconductor firm is count variable with many zeroes and ones, we use Poisson-based econometric models and estimation methods. As in Hausman, Hall, and Griliches (1984), we hypothesize that the expected number of patents applied for during the year is an exponential function of the firm's R\&D spending and other characteristics $X_{\mathrm{it}}$ :

$$
\mathrm{E}\left[\mathrm{p}_{\mathrm{it}} \mid \mathrm{X}_{\mathrm{it}}\right]=\lambda_{\mathrm{it}}=\exp \left(\mathrm{X}_{\mathrm{it}} \beta+\gamma_{\mathrm{t}}\right)
$$

where $i$ indexes the firm and $t$ indexes the year. $\gamma_{t}$ is an overall year specific mean that measures the average patenting rate across all firms, adjusting for the changing mix of firms in the sample. We estimate this model using maximum likelihood for the Poisson distribution, but we report "robust" standard errors. Gourieroux, Montfort, and Trognon (1984) have shown that the Poisson model is in the linear exponential class, so our estimates are consistent if the mean specification is correct. The robust standard errors are consistent even under misspecification of the distribution. We also report the results of a Lagrange multiplier test for overdispersion of the negative binomial (2) type that is due to Cameron and Trivedi (1998) in the tables. ${ }^{41}$ Rejection can be interpreted as a rejection of the pure Poisson model in favor of a model where the variance is proportional to the mean.

The coefficients from the above model have an elasticity interpretation:

$$
\left(1 / \lambda_{\mathrm{it}}\right)\left(\mathrm{d} \lambda_{\mathrm{it}} / \mathrm{d} \mathrm{X}_{\mathrm{it}}\right)=\beta
$$

and the changes in the $\gamma_{\mathrm{it}} \mathrm{s}$ measure the growth of the patenting propensities over time that is not accounted for by changes in the firm's characteristics:

$$
\Delta \log \lambda_{\mathrm{it}}=\mathrm{X}_{\mathrm{it}} \beta+\gamma_{\mathrm{t}}-\left(\mathrm{X}_{\mathrm{it}-1} \beta+\gamma_{\mathrm{t}-1}\right)=\Delta \mathrm{X}_{\mathrm{it}} \beta+\gamma_{\mathrm{t}}-\gamma_{\mathrm{t}-1}
$$


Therefore, we will focus on the time pattern of the $\gamma$ estimates when we discuss the results of estimating the patent production function, since we expect there to be considerable residual growth even after we adjust for the changing characteristics of the firms in the industry.

Traditionally, the most important variable in the patent production function is $R \& D$ spending by the firm, and much of the early work that estimated this model focused on the question of whether one could measure the lag structure for the production of patents from past R\&D spending. ${ }^{42}$ This literature largely concludes that the lag structure is very poorly identified because of the high within-firm correlation of $R \& D$ spending over time. When many lags are included in the model, the estimate of the sum of the coefficients is roughly the same as the estimated coefficient of contemporaneous R\&D when no lags are included; in addition, most of the contribution comes from the oldest and the newest R\&D lag included. For this reason and because many of our firms have very short R\&D histories, we do not try to estimate the lag structure of the $R \& D$ contribution in this paper, but use only the contemporaneous level of $R \& D$ spending in our specifications. $^{43}$

A second result in the previous literature on patent production is that when one allows for permanent differences across firms in the propensity to patent, the sum of the R\&D lag coefficients falls, mostly because the coefficient on the oldest lag becomes insignificant. In the case here, we are interested in the firm effects themselves, and so we do not want to begin with a model that sweeps them out. Thus our base specification of the patent production function includes the following variables:

- $\quad \mathbf{R} \& D$ spending during the year in which the patents are applied for, deflated in 1992 dollars, in logarithms.

- $\quad$ The size of the firm, measured as the logarithm of employment. The larger the firm, the more likely that it will be approached by key patent holders in the industry for a share of those royalties. In addition, there may be economies of scale in generating patents, due to the fixed cost of maintaining a legal department that can handle intellectual property questions (confirmed in our interviews).

- The capital-intensity of the firm, measured as the logrithm of the ratio of deflated (1992\$) plant and equipment to employees (i.e., capital-labor ratio). Capitalintensive firms may need to "protect themselves" more fully against the threat of litigation (and the potential risk of preliminary injunctions; see Lanjouw and Lerner 1997), given the expense of maintaining and operating state-of-the-art semiconductor fabs and the subsequent costs associated with a halt in production. ${ }^{44}$

- $\quad$ The age of the firm, measured as its age in 1996, to avoid confounding this variable with the time effects.

- $\quad$ The type of firm (manufacturer or design firm). Manufacturers need rights to a broad range of process and product technologies whereas design firms implicitly purchase process technologies via their manufacturing contracts with foundries. 
- $\quad$ Time dummies, annual, 1980-94.

After presenting the base specification, and discussing the results, we augment our specification with a series of variables that explore the differences in the patent equation for firms that entered after 1982, and then for the behavior of all firms after 1982. We add a dummy variable that is equal to one if the firm was established after 1982, and also interact this variable with the R\&D spending levels and size of the firm. There are 44 such firms in our sample. We examine whether the post-82 entrants patent more (or less) intensively than the other firms in our sample (controlling for other firm characteristics). ${ }^{45}$

\subsection{Preliminary Results}

Table 2 presents the results of estimating our base specification for 1980-94 using maximum likelihood methods and the Poisson density function. As should be clear from the above discussion, the data set is a panel and the unit of analysis is a firm-year. Standard error estimates robust to heteroskedasticity and misspecification of the distribution are shown in parentheses. The estimates of the elasticity of patenting with respect to $R \& D$ spending in semiconductors alone are similar to those previously obtained using data for the whole manufacturing sector in the 1970s. For example, Hausman, Hall, and Griliches (1984) obtained an R\&D elasticity of 0.87 (0.004) using the Poisson distribution and an elasticity of $0.75(.02)$ and variance parameter of 0.04 (0.002) using the negative binomial distribution for 128 large firms. Hall, Griliches, and Hausman (1986) obtained a somewhat lower elasticity of 0.52 for a larger sample of 642 firms. In the latter case, the log of capital stock was also included in the equation and the total scale coefficient (the sum of the two coefficients) was 0.66 , somewhat closer to our estimate of 0.98 .

When we add firm size and capital intensity to the model, the R\&D coefficient falls sharply because of collinearity between the two size measures, $R \& D$ and employment, but the total scale coefficient is about the same (0.99). The explanatory power of the model improves also, with a substantial increase in the likelihood and a fall in value of the overdispersion test statistic. Inclusion of the other variables in the model does not affect these basic results.

In column (3) we add the age of the firm, together with dummies for having manufacturing facilities and for Texas Instruments (TI). It is well-known that Texas Instruments pursues an aggressive intellectual property strategy, harvesting substantial royalties from its patent portfolio. TI's patenting propensity reflects an aggressive IP strategy: the firm obtains an average of 75 percent more patents than other firms in the sample, even controlling for its size and R\&D. Texas 
Instruments is an outlier among firms in our sample in several ways-most importantly, it is the only firm in our sample that had a large patent portfolio (in absolute terms and relative to its $R \& D$ spending) in the early 1980s when US patent rights were strengthened; Texas Instruments is also more diversified than the other semiconductor manufacturers in our sample. ${ }^{46}$ In column (3) and in the rest of the results in our paper, the patent equation easily passes the overdispersion test, so we conclude that controlling for the unique nature of TI leaves us with a sample of firms whose patenting behavior is consistent with the conditional Poisson model (that is, the variance conditional on firm characteristics is approximately equal to the conditional mean).

Turning to the coefficients of interest, we find that older firms have about a 40 percent lower patenting propensity when we control for their typically much larger size and R\&D programs, and for the fact that they are more likely to have invested in manufacturing facilities. In fact, owning a fab also lowers the probability of a patent application, but the result is not significant. Later on in the paper we show that design firms do indeed seem to have a higher patenting propensity than manufacturers, once we control for the higher capital-labor ratio of manufacturing firms.

The estimates in Table 2 yield two striking results. The figure at the bottom of Table 2 plots the year dummies for the 4 sets of estimates, normalized so that they are equal in $1980 .{ }^{47}$ These estimates make it quite clear that controlling for changes in the mix of semiconductor firms over time increases rather than reduces the rise in patenting propensity that we saw in Figure 1. More specifically, these estimates suggest that the patent propensity of the firms in our sample increased at a steady rate of 10 percent per year after the 1982 introduction of the Court of Appeals for the Federal Circuit until 1994, for a total increase of approximately 120 percent. In addition, we find that the age effect is largely due to the fact that post-1982 entrants have a higher average propensity to patent, all else equal, which directly contradicts the regulatory capture hypothesis suggested by Kortum and Lerner. ${ }^{48}$

In Tables 3 and 4, we revisit the question of whether the increase in patenting was driven by the wave of firms that entered the industry since 1982 or by the behavior of capital-intensive manufacturers, who are arguably more subject to hold-up threats given their large investments in fabrication plants. To explore this, we show three variations of the basic specification in Tables 3 (post-1982 entry) and 4 (Manufacturing vs Design Firms): a separate intercept in column (1), different slopes in column (2), and separate trends in columns (3) and (4). 
In Column 1 of Table 3, we find that post-1982 entrants are, on average, almost 35\% more likely to patent, controlling for other characteristics of these firms. We can explain this fact by noting that their patent propensity equation (shown in Column 2) is different, in that R\&D investment is a better predictor than capital intensity for these firms. Once we allow for this difference, the average difference in patenting propensity is insignificant. On the other hand, in column (3) and in the figure below the table, we see that these entrants have a very different time pattern in their patenting propensities: they are much higher in the 1986-1991 period, and then fall back to the level of the other firms in 1992; some of this difference goes away when we allow these firms to have a separate patent propensity equation (column (4)). We conclude that there is limited evidence for a higher patenting propensity on the part of more recent entrants, perhaps partly due to the need for patents in order to secure venture capital financing (which will operate as a selection mechanism on entry and is quite consistent with entrant firms having a higher but falling patent propensity over time).

Table 4 provides similar evidence for design firms. ${ }^{49}$ Like the post-1982 entrants, roughly half of which were design firms, these firms have a higher patenting propensity than predicted by their characteristics and this propensity depends more on R\&D intensity and less on capital intensity (not surprisingly, since they do not invest heavily in manufacturing facilities). A slight puzzle is that they are 200 percent more likely to patent than predicted by their own patenting propensity equation. A detailed examination of the data failed to explain this as due to outliers of some kind, but the result is very imprecise and based on small samples; also, remember that the raw data gave a lower patenting-R\&D ratio for these firms, so apparently our cleaning process favored design firms with higher patenting propensities (as we would expect if the less successful firms exited).

Our interpretation of the results in Table 4 is the following: capital intensity is an important explanatory variable for patenting in manufacturing firms because of the "hold-up" danger these firms face if they do not have adequate intellectual property protection or at least adequate defense against the IP protection of other firms for all the key steps in their manufacturing process. However, it is less important for design firms. When we require both sets of firms to have the same equation except for the intercepts or time trend, the differences between them are not very significant (note the chi-squared for the time trends in column 3 of Table 4), because the equation for the design firms is basically misspecified. When we allow each group to have its own slope coefficients, we then see a larger difference in patenting propensities between 
manufacturing and design firms, but the sample of design firms is too small for precise measurement (the chi-squared for differences in the time dummies in column 4 of Table 4 is 27.5 with 8 degrees of freedom, which is significant). Thus, we conclude that the results support both the idea that capital-intensive firms have increased their patenting to protect their investments in state-of-the-art manufacturing facilities and that design firms find patenting important to enter niche markets and secure financing.

\section{Exploring alternative hypotheses}

In the previous sections, we have demonstrated that a surge in the patent propensities of semiconductor firms has indeed taken place since the "pro-patent" shift US legal environment in the early 1980, and that the surge is driven by the aggressive patenting activities of large-scale manufacturing firms as well as the increased reliance on patents by entrant firms. In our opinion, these results are consistent with a variant of Kortum and Lerner's "friendly court" hypothesis, but one that allows for strategic behavior among firms. Patent rights are inherently a right to exclude. In an industry where the pace of technology is rapid, innovation is cumulative, and ownership of the technologies used in production is fragmented across a diverse set of actors, the strengthening of US patent rights increases the risk that one holder of property rights can effectively exclude, or "block", another from using the technology embodied in the patent (Merges and Nelson 1990; Scotchmer 1991, 1996). This concern is especially salient among firms that have made costly and rapidly-depreciating investments in wafer fabrication facilities, which inherently utilize a "thicket" of innovations developed by many parties. In order to obtain the rights to infringe patents held by external parties and to improve their leverage in negotiations with other patent owners, these firms amass large portfolios of patents. With the strengthening of US patent rights, the expected benefits of owning US patents (for offensive and defensive reasons) began to outweigh their expected costs.

Although our empirical results and interviews with firms underline the importance of stronger patent rights on the increased patent propensities of firms in this industry, we explore several alternative hypotheses identified in the cross-industry analysis by Kortum and Lerner (1997). First, if firms have redirected more of their R\&D investments toward applied rather than basic research, we might also see an increased patent yield of $R \& D$ dollars over time. There was little indication from our interviews that such an industry-wide shift occurred in this industry that would explain the patterns that we observe. We did, however, observe a general belief that it is remarkably easy for these firms to obtain patent rights from the US Patent and Trademark Office 
and, in the view of most representatives and executives we interviewed, the standards of patentability have been lowered (especially the standard that an invention must be "non-obvious" in order to be eligible for a patent award). Although the ease with which firms obtain issued patents may have increased over time, there is little reason to believe that procedures at USPTO would disproportionately favor patents in semiconductor-related technologies.

A final explanation for the surge in patenting is that firms have improved their ability to manage the innovation process and the "productivity of R\&D" has therefore improved: $R \& D$ expenditures have remained relatively stable while the patented "output" of that R\&D has increased. Through a process of elimination, Kortum and Lerner (1997) supported the view that "managerial improvements" (not the "friendly court" or a shift toward applied research) underpinned the cross-industry increase in US patenting.

Our interviews suggest a very different interpretation of the "managerial improvement" hypothesis, at least in the semiconductor industry. The surge in patents relative to R\&D spending may indeed reflect important managerial changes, but in how firms manage the $R \& D$ output, not necessarily the $R \& D$ input side of the innovation process. For example, most of the firms we interviewed had overhauled their internal patent procedures during the past 5-10 years by hiring more in-house patent attorneys, rewarding firms' engineers with bonuses for patented inventions, elevating the role of patent attorneys within the firm and expanding their involvement in corporatewide activities, (such as strategic alliances, licensing, and litigation decisions), and creating inhouse "patent committees" to oversee, and simplify, the otherwise time-consuming process of writing, filing, and revising patent applications. Some manufacturers noted that they are "harvesting" more of their latent inventions, while others noted that they are "ramping up" their patent filings in order to amass more sizeable patent portfolios. Although the increased sophistication of design tools may have aided firms' ability to innovate in the product areas, the most dramatic alteration in the internal processes appeared to be directed toward the management of the patent process itself.

The next step in our empirical analysis will test between these "patent" versus "R\&D" productivity hypotheses more explicitly by controlling for changes in the "quality" of these firms' patents over time (i.e., by examining changes in both the number of claims in these firms' patent portfolios over time and in the number of subsequent citations that their patents receive). ${ }^{50}$ This will enable us to test whether firms are applying for an increasing number of "lesser quality" patents over time (as implied by a "harvesting" strategy whereby firms are patenting a greater 
share of their overall inventions over time), or whether, in fact, the average quality of their patent portfolios remains constant over time (as implied by an increase in research productivity alone).

\section{Conclusion}

"One of the more important debates for the rest of this century, as the power and role of intellectual property enforcement moves to center stage, may well be whether the incentives created by vigorous enforcement of broad, vaguely defined property rights in ideas and information outweigh the tendency of such enforcement to discourage new entry by would-be challengers" (Taylor and Higgins 1994, p.2). ${ }^{51}$

Our preliminary evidence suggests that the "pro-patent" shift in the 1980s has altered the patent strategies of semiconductor firms, but in ways that go beyond the "classic" incentives provided of the patent system. On the one hand, stronger patent rights may have facilitated specialization in the industry and may well have supported a market for know-how exchange involving entrant firms (Merges 1996; Arora and Fosfuri 1998). On the other hand, such positive effects are countered by a socially inefficient process whereby firms amass vast patent portfolios simply as "bargaining chips." In essence, a "patent portfolio race" may ensue. In principle, patent portfolio racing is not an inevitable outcome of strengthening patent rights in cumulative technological areas. If patent rights were strictly awarded to inventors of "non-obvious", "useful", and "novel" inventions, then it should become increasingly difficult to obtain a patent when a thicket of prior art exists, and the number of successful patent applications should fall.

It is also clear that there are substantial costs to using the patent system as a means of ensuring access to the necessary complementary technology. There is the cost of staffing an internal patent office, the opportunity cost of engineering time and effort, and the direct costs of filing and maintaining patents once granted. At the same time, there is a dubious overall social gain to other firms in the industry from the information disclosed in patents related to semiconductor technologies. An interesting topic for future research is why the exchange of intellectual property in this industry has evolved in this way, rather than towards the development of shared patent pools. 


\section{References}

Arora, A. and A. Fosfuri (1998). "Licensing in the Chemical Industry," conference paper, Intellectual Property and Industry Competitive Standards, Stanford University, April.

Arora, A. and A. Gambardella (1994). "The Changing Technology of Technological Change: General and Abstract Knowledge and the Division of Innovative Labour," Research Policy 23: 523-532.

Barton, J.H. and S.J. Parapatt (1998). "Patent Litigation and Its Relationship to Industry Structure and Competition in the Photographic Film and Camera Industry," conference paper, Intellectual Property and Industry Competitive Standards, Stanford University, April.

Blundell, R., R. Griffith, and F. Windmeijer (1997). "Individual Effects and Dynamics in Count Data Models," unpublished manuscript (August).

Cameron, A.C. and P.K. Trivedi (1998). Regression Analysis of Count Data (Cambridge, UK: Cambridge University Press).

Cohen, W.M., R.R. Nelson, and J. Walsh (1996). "A First Look at the Results of the 1994 Carnegie-Mellon Survey of Industrial R\&D in the United States," unpublished manuscript, February 28.

Cohen, W.M., R.R. Nelson, and J. Walsh (1997). "Appropriability Conditions and Why Firms Patent and Why They Do Not in the American Manufacturing Sector," unpublished manuscript, June 24 .

Gourieroux, C., A. Montfort, and A. Trognon (1984). "Pseudo Maximum Likelihood Methods: Applications to Poisson Models," Econometrica 52(3): 701-720.

Green, J.R and S. Scotchmer (1995). "On the division of profit in sequential innovation," Rand Journal of Economics, Spring 26(1): 20-33.

Grindley, P.C and D.J. Teece (1997). "Managing Intellectual Capital: Licensing and CrossLicensing in Semiconductors and Electronics," California Management Review 39(2): 1-34.

Griliches, Z. 1990. "Patent Statistics as Economic Indicators: A Survey," Journal of Economic Literature XXVIII: 1661-1707.

Griliches, Z., B.H.Hall, and A. Pakes (1991). "R\&D, Patents and Market Value Revisited: Is there a Second (Technological Opportunity) Factor?" Economics of Innovation and New Technology 1: 183-202.

Hall, B. H., and C. Cummins (1999). TSP Reference Manual, Version 4.5, Palo Alto, CA: TSP International.

Hall, B. H., Z. Griliches, and J. A. Hausman (1986). "Patents and R\&D: Is There a Lag?," International Economic Review 27: 265-283. 
Hall, B. H., Z. Griliches, and J. A. Hausman (1986). "Patents and R\&D: Is There a Lag?," International Economic Review 27: 265-283.

Hall, B. H., A. Jaffe, and M. J. Trajtenberg (1998). "Market Value and Patent Citations: A First Look," Nuffield College, Oxford, UC Berkeley, Brandeis University, Tel Aviv University, and NBER: work in progress (September).

Ham, R.M., G.L. Linden, and M.M. Appleyard (1998). "The Evolving Role of Semiconductor Consortia in the United States and Japan," California Management Review 41: 137-163.

Hausman, J. A., B. H. Hall, and Z. Griliches (1984). "Econometric Models for Count Data with an Application to the Patents-R\&D Relationship," Econometrica 52: 909-938.

Integrated Circuit Engineering Corporation (1976-98). Status: A Report on the Integrated Circuit Industry. (Scottsdale, AZ: Integrated Circuit Engineering Corporation).

Keustermans, J.A. and I.M. Arckens (1994). A Practical Guide to the International Distribution and Protection of Software and Integrated Circuits. (New York, N.Y: Times Mirror Books).

Kortum, S. and J. Lerner (1998). "Stronger Protection or Technological Revolution: What is Behind the Recent Surge in Patenting?," Carnegie-Rochester Conference Series on Public Policy 48: 247-304.

Lanjouw, J.O. (1994), "Economic Consequences of a Changing Litigation Environment: The Case of Patents," NBER working paper no. 4835 (August).

Lanjouw, J.O. and J. Lerner (1997). "Preliminary Injunctive Relief: Theory and Evidence from Patent Litigation," Harvard Business School working paper no. 96-068, and NBER working paper no. 5689.

Lanjouw, J.O. and M. Schankerman (1997). "Stylized Facts of Patent Litigation: Value, Scope, and Ownership," manuscript (August).

Lerner, J. (1995). "Patenting in the Shadow of Competitors," Journal of Law and Economics, (October): 463-495.

Lewis, T.G. (1995). "Comment: Semiconductor Chip Process Protection; Legal Issues in the Information Revolution Symposium,” Houston Law Review 32: 555-612.

Levin, R.C. (1982). "The Semiconductor Industry," in Richard R. Nelson, ed., Government and Technical Progress: A Cross-Industry Analysis (Pergamon Press, 1982).

Levin, R.C., A.K. Klevorick, R.R. Nelson, and S.G. Winter (1987). "Appropriating the Returns from Industrial Research and Development," Brookings Papers on Economic Activity (3): 783820.

Macher, J., D.C. Mowery, and D. Hodges (1998). "Reversal of Fortune? The Recovery of the U.S. California Management Review 41(1): 107-136. 
Mazzoleni, R. and R.R. Nelson (1997). "The Benefits and Costs of Strong Patent Protection: A Contribution to the Current Debate," working paper (November 13).

Merges, R.P. (1997). Patent Law and Policy: Cases and Materials. Second edition. (Charlottesville, VA: The Mitchie Company).

Merges, R.P. (1996). Contracting into Liability Rules: Intellectual Property Rights and Collective Rights Organizations," California Law Review 84(5): 1293-1393.

Merges, R.P. and Nelson, R.R. (1990). "On the Complex Economics of Patent Scope," Columbia Law Review 90(4): 839-916.

Montalvo, J. G. (1997). Journal of Business and Economic Statistics 15(1): 82-89.

Nies, H.W. (1993). "Ten Years of Patent Law Development Under the U.S. Court of Appeals for IIC 24(6): 797-803.

O’Donoghue, T. (1998). "A patentability requirement for sequential innovation," Rand Journal of Economics, Winter 29(4): 654-679.

O'Donoghue, T., S. Scotchmer, and J-F Thisse (1998). "Patent Breadth, Patent Life, and the Pace Journal of Economics and Management Strategy, Spring 7(1): 1-32.

Pakes, A., and Z. Griliches (1980). "Patents and R\&D at the Firm Level: A First Look," Economic Letters 5: 377-381.

Parr, R.L. and P.H. Sullivan (1996). Technology Licensing: Corporate Strategies for Maximizing Value. (New York, NY: John Wiley \& Sons, Inc.)

Reinganum, J.F. (1989). "The Timing of Innovation: Research, Development, and Diffusion," in R. Schmalansee and R.D. Willig, eds., Handbook of Industrial Organization. (New York: NorthHolland).

Scotchmer, S. (1996). "Protecting Early Innovators: Should Second-Generation Products Be Rand Journal of Economics 27: 322-331.

Scotchmer, S. (1991). "Standing on the Shoulders of Giants: Cumulative Innovation and the Patent Journal of Economic Perspectives 5:29-41.

Scotchmer, S. and J. Green (1990). "Novelty and Disclosure in Patent Law," Rand Journal of Economics, Spring 21(1): 131-146.

Taylor, C.T. and Z. A. Silberston (1973). The Economic Impact of the Patent System: A Study of the British Experience (Cambridge, UK: University Press).

Taylor, R.P. (1992). "1992 Patent Enforcement Trends," unpublished legal monograph, Howrey and Simon, Palo Alto, California. 
Taylor, R.P. and M.J. Higgins (1993). "Innovation and Antitrust," unpublished legal monograph, Howrey and Simon, Palo Alto, California.

Von Hippel, E. (1988). The Sources of Innovation. (Oxford, U.K.: Oxford University Press). 
Table 1

Sample Statistics

US Semiconductor Sample before Cleaning 1525 Observations (110 Firms) 1965-1997

\begin{tabular}{|c|c|c|c|c|c|c|c|}
\hline Variable Name & Mean & DS & Median & Firsto & Third & Min & Max \\
\hline Patent Applications & 11.10 & 43.68 & 1 & 0 & 4 & 0 & 565 \\
\hline R\&D (\$M 1992)* & 4.77 & 2.14 & 4.63 & 0.55 & 15.05 & 0 & 2116.8 \\
\hline Employment (1000s) & 0.645 & 1.77 & 0.551 & 0.192 & 1.797 & 0 & 89.9 \\
\hline $\begin{array}{l}\text { P\&E per employee* } \\
\text { (\$1000 1992) }\end{array}$ & 24.1 & 0.84 & 24.0 & 13.10 & 43.6 & 0.8 & 252.8 \\
\hline Age of Firm & 24.4 & 12.9 & 22 & 13 & 35 & 3 & 60 \\
\hline$D(R \& D=0)$ & 0.069 & $(\mathrm{~N}=105)$ & & & & & \\
\hline $\mathrm{D}($ entered after 1982) & 0.298 & $(\mathrm{~N}=454)$ & & & & & \\
\hline D(Fabless) & 0.199 & $=303)$ & & & & & \\
\hline
\end{tabular}

US Semiconductor Sample Used in Rearessions 679 Observations (72 Firms) $\quad$ 1980-1994

\begin{tabular}{|l|cc|ccc|cc|}
\hline Variable Name & Mean & SD & Median & First 0 & Third O & Min & Max \\
\hline Patent Applications & 17.32 & 58.38 & 1 & 0 & 7 & 0 & 565 \\
R\&D (\$M 1992) & 4.76 & 2.21 & 5.63 & 0.58 & 16.75 & 0 & 1061.4 \\
Employment (1000s) & 0.624 & 1.75 & 0.561 & 0.185 & 1.797 & 0 & 89.9 \\
P\&E per employee* & 27.8 & 0.79 & 29.5 & 16.6 & 48.1 & 0.8 & 165.6 \\
$\begin{array}{l}(\$ 1000 \text { 1992) } \\
\text { Age of Firm }\end{array}$ & 27.0 & 11.8 & 28 & 16 & 36 & 4 & 60 \\
D(R\&D=0) & 0.050 & $(\mathrm{~N}=34)$ & & & & & \\
D(entered after 1982) & 0.168 & $(\mathrm{~N}=114)$ & & & & & \\
D(Fabless) & 0.108 & $(\mathrm{~N}=73)$ & & & & & \\
\hline
\end{tabular}

*Geometric means are shown for these variables, along with the standard deviation of the log. 
Table 2

Patenting Propensity Estimates

US Semiconductor Firms 1980-1994

679 Observations

\begin{tabular}{|c|c|c|c|c|c|c|}
\hline Variable Name & $\begin{array}{c}\text { Poisson } \\
\text { (1) }\end{array}$ & $\begin{array}{l}\text { Poisson } \\
\text { (2) }\end{array}$ & \multicolumn{2}{|c|}{$\begin{array}{l}\text { Poisson } \\
\text { (3) }\end{array}$} & \multicolumn{2}{|c|}{$\begin{array}{c}\text { Poisson } \\
(4)\end{array}$} \\
\hline $\begin{array}{l}\log R \& D \\
(\$ 1992 M)\end{array}$ & $0.975 \quad(0.042)$ & $0.189 \quad(0.099)$ & 0.141 & $(0.115)$ & 0.198 & $(0.112)$ \\
\hline $\begin{array}{l}\text { Dummy for no reported } \\
\text { R\&D }\end{array}$ & $-1.308 \quad(0.804)$ & $-1.744 \quad(0.815)$ & -1.720 & $(0.820)$ & -1.841 & $(0.813)$ \\
\hline $\begin{array}{l}\text { Log firm size } \\
\text { (1000s employees) }\end{array}$ & & $0.798 \quad(0.093)$ & 0.798 & $(0.133)$ & 0.679 & $(0.114)$ \\
\hline $\begin{array}{l}\text { Log P\&E per employee } \\
(\$ 1987 K)\end{array}$ & & $0.213 \quad(0.144)$ & 0.380 & $(0.136)$ & 0.456 & $(0.150)$ \\
\hline $\begin{array}{l}\text { Dummy for firms with } \\
\text { fabrication plants }\end{array}$ & & & -0.309 & $(0.202)$ & -0.231 & $(0.236)$ \\
\hline $\begin{array}{l}\text { Log firm age in } 1996 \\
\text { (number of years) }\end{array}$ & & & -0.484 & $(0.174)$ & & \\
\hline $\begin{array}{l}\text { Dummy for post-1982 } \\
\text { entrants }\end{array}$ & & & & & 0.273 & $(0.200)$ \\
\hline Dummy (Texas Instruments) & & & 0.746 & $(0.100)$ & 0.697 & $(0.100)$ \\
\hline Test for overdispersion ( $p$-value) & $56.7(.000)$ & $7.6(.006)$ & 2.3 & 32) & 2.4 & 23) \\
\hline Log Likelihood & $-3,897.6$ & $-2,943.2$ & & & & 5.4 \\
\hline Number of Parameters & 17 & 19 & & & & \\
\hline Chi-squared (p-value) & $599.0(.000)$ & $152.0(.000)$ & 69.7 & $000)$ & 67.2 & $000)$ \\
\hline
\end{tabular}

Heteroskedastic-consistent standard errors are shown in parentheses.

The method of estimation is maximum likelihood for the Poisson model (which is generalized ML for the exponential mean function).

The chi-squared is a Wald test for the specification in the column to the left versus the current column (col.4 is tested vs. col. 2).

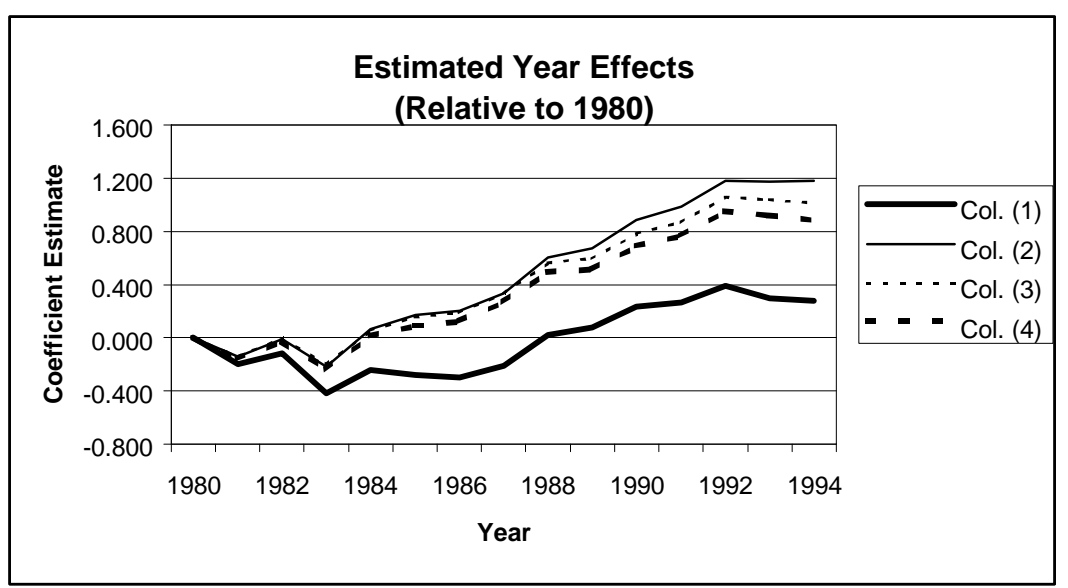


Table 3

Patenting Propensity Estimates

US Semiconductor Firms 1980-1994

679 Observations

\begin{tabular}{|c|c|c|c|c|c|c|c|c|}
\hline Variable Name & \multicolumn{2}{|c|}{ (1) } & \multicolumn{2}{|c|}{ (2) } & \multicolumn{2}{|c|}{ (3) } & \multicolumn{2}{|c|}{ (4) } \\
\hline \multirow[b]{2}{*}{ Intercept } & \multicolumn{8}{|c|}{ Pre-1982 Entrants } \\
\hline & \multicolumn{2}{|c|}{ year dummies } & \multicolumn{2}{|c|}{ year dummies } & \multicolumn{2}{|c|}{ year dummies } & \multicolumn{2}{|c|}{ year dummies } \\
\hline $\begin{array}{l}\text { Log firm size } \\
\text { (1000s employees) }\end{array}$ & 0.870 & $(0.030)$ & 0.883 & $(0.031)$ & 0.877 & $(0.030)$ & 0.884 & $(0.030)$ \\
\hline $\begin{array}{l}\text { Log R\&D per employee } \\
\text { (\$1992 1000s) }\end{array}$ & 0.227 & $(0.098)$ & 0.129 & $(0.108)$ & 0.210 & $(0.098)$ & 0.128 & $(0.108)$ \\
\hline $\begin{array}{l}\text { Dummy for no reported } \\
R \& D\end{array}$ & -1.566 & $(0.843)$ & -1.668 & $(0.850)$ & -1.585 & $(0.843)$ & -1.664 & $(0.849)$ \\
\hline $\begin{array}{l}\text { Log P\&E per employee } \\
\text { (\$1992 1000s) }\end{array}$ & 0.429 & $(0.140)$ & 0.516 & $(0.150)$ & 0.424 & $(0.138)$ & 0.495 & $(0.151)$ \\
\hline \multirow[t]{2}{*}{ Dummy for Texas Inst. } & 0.711 & $(0.097)$ & 0.676 & $(0.102)$ & 0.689 & $(0.095)$ & 0.665 & $(0.099)$ \\
\hline & \multicolumn{8}{|c|}{ Post-1982 Entrants } \\
\hline Intercept & 0.335 & $(0.178)$ & 0.124 & $(0.719)$ & year & nmies & year c & nmies \\
\hline $\begin{array}{l}\text { Log firm size } \\
\text { (1000s employees }\end{array}$ & same & & 0.960 & $(0.099)$ & same & & 1.067 & $(0.116)$ \\
\hline $\begin{array}{l}\text { Log R\&D per employee } \\
\text { (\$1992 1000s) }\end{array}$ & same & & 0.701 & $(0.148)$ & same & & 0.730 & $(0.144)$ \\
\hline $\begin{array}{l}\text { Dummy for no reported } \\
R \& D\end{array}$ & same & & -- & & same & & -- & \\
\hline $\begin{array}{l}\text { Log P\&E per employee } \\
\text { (\$1992 1000s) }\end{array}$ & same & & 0.099 & $(0.197)$ & same & & 0.210 & $(0.232)$ \\
\hline $\begin{array}{l}\text { Test for overdispersion ( } p \text {-value) } \\
\text { Log Likelihood } \\
\text { Number of Parameters } \\
\text { Chi-squared (p-value) }\end{array}$ & $\begin{array}{c}2.20 \\
-2\end{array}$ & $\begin{array}{l}\text { 138) } \\
0.6\end{array}$ & $\begin{array}{r}2.43 \\
-2 \\
101 \\
\end{array}$ & $\begin{array}{l}119) \\
1.9 \\
.000) \\
\end{array}$ & $\begin{array}{r}2.66 \\
-2 \\
27 .\end{array}$ & $\begin{array}{l}103) \\
7.6 \\
000) \\
\end{array}$ & $\begin{array}{r}3.37 \\
-2, \\
102 .\end{array}$ & $\begin{array}{l}067) \\
2.0 \\
.000) \\
\end{array}$ \\
\hline
\end{tabular}

See notes to Table 2. Chi-squared tests are col. 2 vs col. 1, col. 3 vs col. 1, col. 4 vs col. 3.

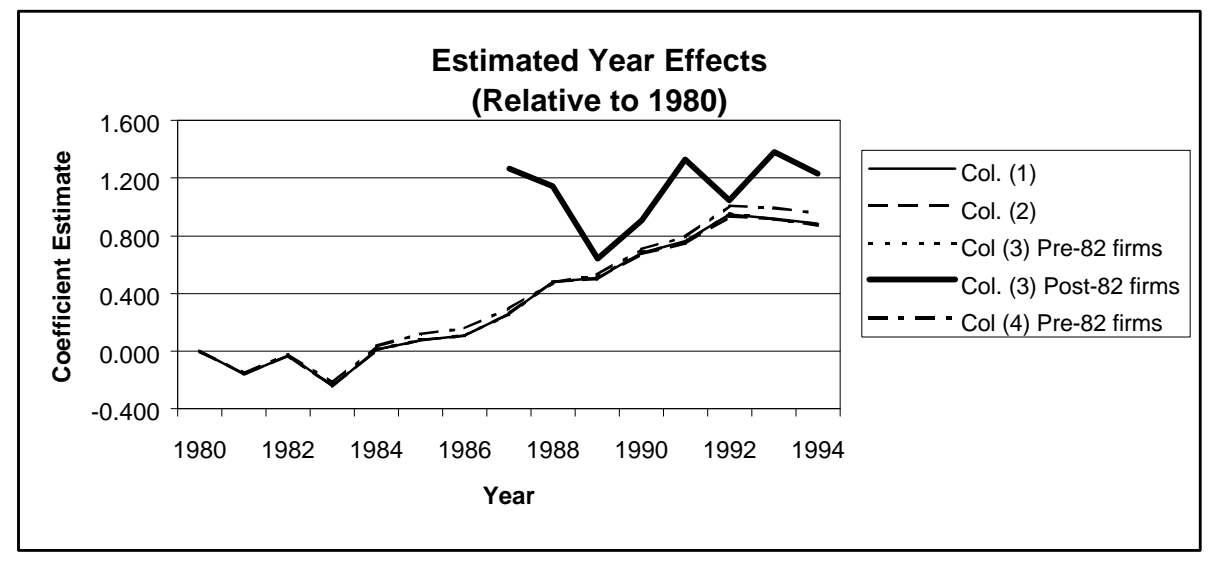


Table 4

Patenting Propensity Estimates

US Semiconductor Firms 1980-1994

679 Observations

\begin{tabular}{|c|c|c|c|c|c|c|c|c|}
\hline \multirow{4}{*}{$\begin{array}{l}\text { Intercept } \\
\text { Log firm size } \\
\text { (1000s employees) }\end{array}$} & \multicolumn{2}{|c|}{ (1) } & \multicolumn{2}{|c|}{ (2) } & \multicolumn{2}{|c|}{ (3) } & \multicolumn{2}{|c|}{ (4) } \\
\hline & \multicolumn{8}{|c|}{ Manufacturing Firm Coefficients } \\
\hline & \multicolumn{2}{|c|}{ year dummies } & \multicolumn{2}{|c|}{ year dummies } & \multicolumn{2}{|c|}{ year dummies } & \multicolumn{2}{|c|}{ year dummies } \\
\hline & 0.863 & $(0.030)$ & 0.857 & $(0.031)$ & 0.863 & $(0.030)$ & 0.857 & $(0.031)$ \\
\hline $\begin{array}{l}\text { Log R\&D per employee } \\
\text { (\$1992 1000s) }\end{array}$ & 0.215 & $(0.113)$ & 0.201 & $(0.114)$ & 0.215 & $(0.113)$ & 0.202 & $(0.114)$ \\
\hline $\begin{array}{l}\text { Dummy for no reported } \\
R \& D\end{array}$ & -1.604 & $(0.846)$ & -1.645 & $(0.846)$ & -1.602 & $(0.846)$ & -1.643 & $(0.846)$ \\
\hline $\begin{array}{l}\text { Log P\&E per employee } \\
(\$ 19921000 \text { s })\end{array}$ & 0.443 & $(0.149)$ & 0.467 & $(0.152)$ & 0.443 & $(0.149)$ & 0.466 & $(0.152)$ \\
\hline \multirow[t]{2}{*}{ Dummy for Texas Inst. } & 0.721 & $(0.101)$ & 0.736 & $(0.105)$ & 0.721 & $(0.102)$ & 0.737 & $(0.105)$ \\
\hline & \multicolumn{8}{|c|}{ Design Firm Coefficients } \\
\hline Intercept & 0.366 & $(0.211)$ & 2.07 & $(1.98)$ & year & mmies & year & nmies \\
\hline $\begin{array}{l}\text { Log firm size } \\
\text { (1000s employees }\end{array}$ & same & & 1.383 & $(0.164)$ & same & & 1.431 & $(0.172)$ \\
\hline $\begin{array}{l}\text { Log R\&D per employee } \\
\text { (\$1992 1000s) }\end{array}$ & same & & 0.587 & $(0.313)$ & same & & 0.598 & $(0.318)$ \\
\hline $\begin{array}{l}\text { Dummy for no reported } \\
\text { R\&D }\end{array}$ & same & & -- & & same & & -- & \\
\hline $\begin{array}{l}\text { Log P\&E per employee } \\
(\$ 19921000 \text { s })\end{array}$ & same & & -0.270 & $(0.312)$ & same & & -0.210 & $(0.296)$ \\
\hline $\begin{array}{l}\text { Test for overdispersion ( } p \text {-value) } \\
\text { Log Likelihood } \\
\text { Number of Parameters } \\
\text { Chi-squared (p-value) }\end{array}$ & $\begin{array}{r}2.00 \\
-2,\end{array}$ & $\begin{array}{l}157) \\
6.4\end{array}$ & $\begin{array}{r}2.15 \\
-2,5 \\
92.0 \\
\end{array}$ & $\begin{array}{l}143) \\
9.3 \\
000) \\
\end{array}$ & $\begin{array}{r}2.0 \\
-2 \\
6.6 \\
\end{array}$ & $\begin{array}{l}153) \\
1.7 \\
474)\end{array}$ & $\begin{array}{r}2.23 \\
-2 \\
110 .\end{array}$ & $\begin{array}{l}135) \\
2.3 \\
.000) \\
\end{array}$ \\
\hline
\end{tabular}

See notes to Table 2. Chi-squared tests are col. 2 vs col. 1, col. 3 vs col. 1, col. 4 vs col. 3.

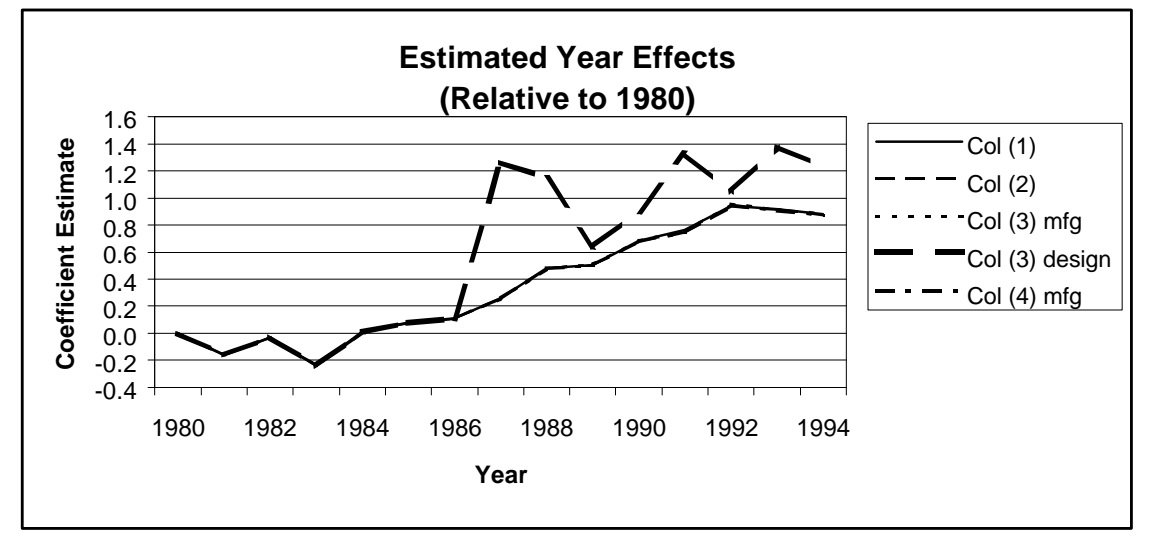




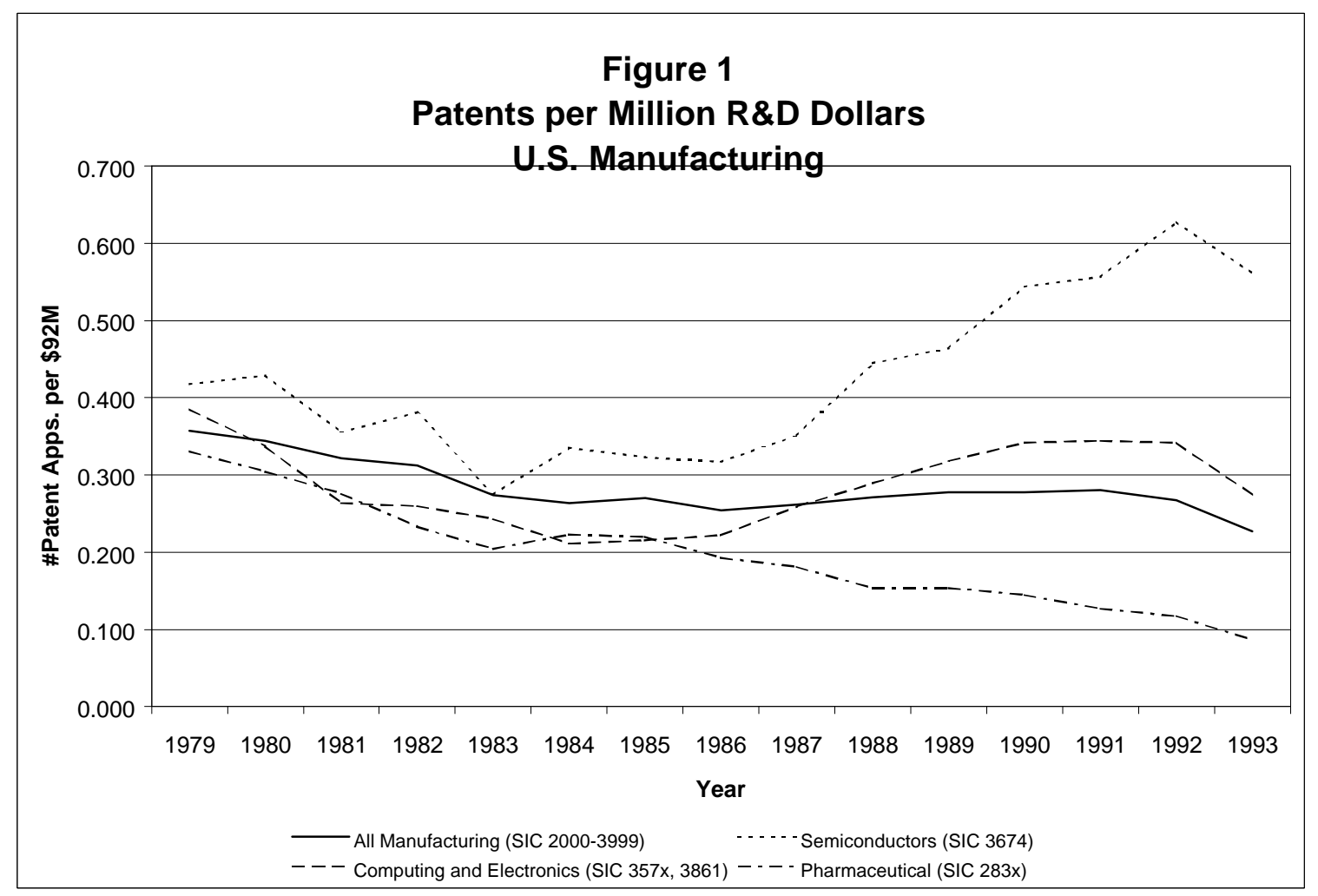


Figure 2

Firms in Sample

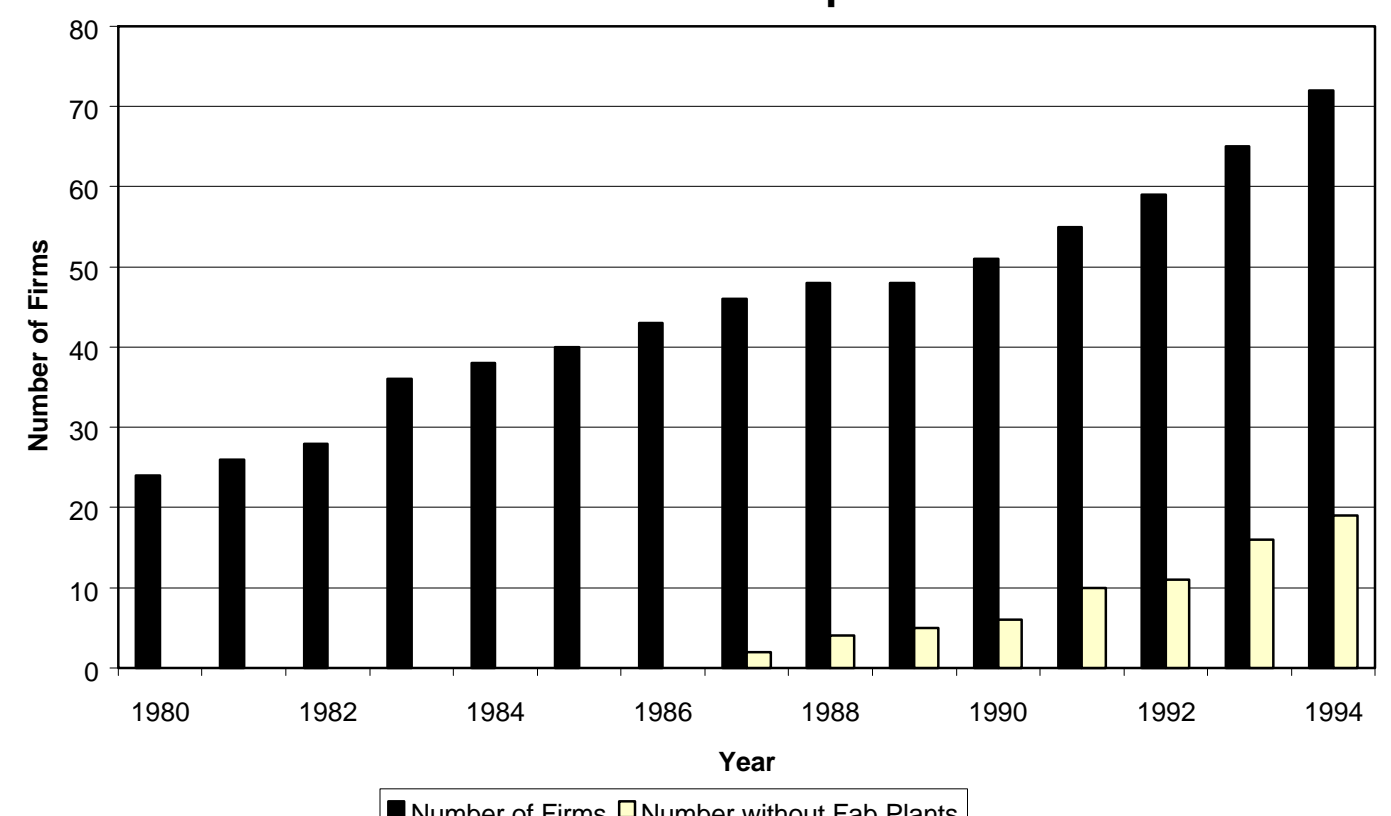

Number of Firms $\square$ Number without Fab Plants 


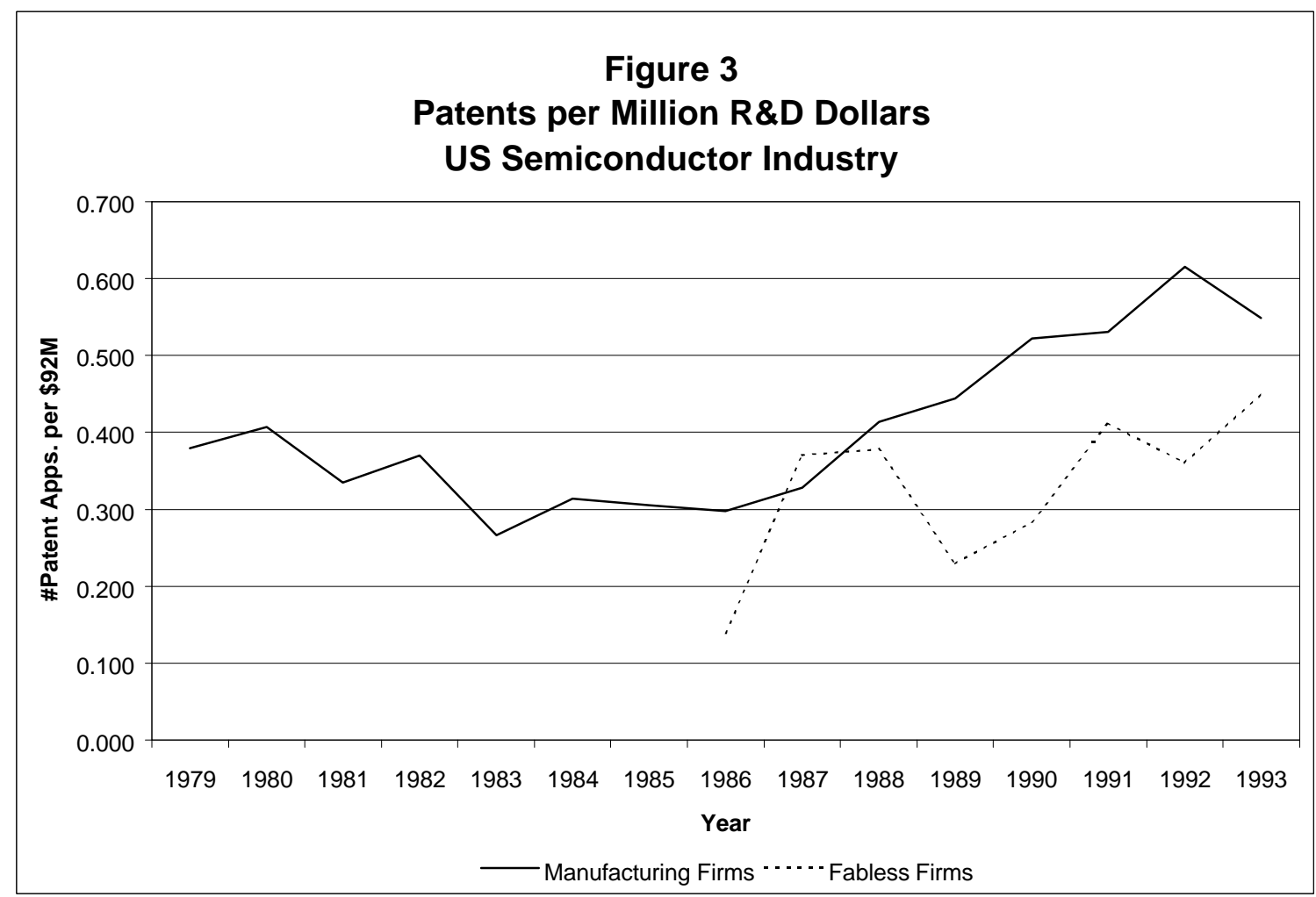


Table A.1

Sample of Firms used in Reqressions - US Semiconductor Manufacturing (SIC 3674)

\begin{tabular}{|c|c|c|c|c|c|c|c|}
\hline CUSIP & Name of Firm & \begin{tabular}{|c|}
$\begin{array}{c}\text { First year } \\
\text { of data }\end{array}$ \\
\end{tabular} & $\begin{array}{c}\text { Last year } \\
\text { of data }\end{array}$ & \begin{tabular}{|c|} 
Sales in \\
$1994(\$ M)$
\end{tabular} & $\begin{array}{c}\text { R\&D in } \\
1994(\$ M)\end{array}$ & \begin{tabular}{|l|} 
Granted 1994 \\
Patent Apps. \\
\end{tabular} & $\begin{array}{c}\text { Total Patents } \\
\text { thru } 1996\end{array}$ \\
\hline 882508 & TEXAS INSTRUMENTS INC & 1965 & 1997 & 10315.0 & 689.00 & 565 & 7433 \\
\hline 637640 & NATIONAL SEMICONDUCTOR CORP & 1967 & 1997 & 2379.4 & 283.10 & 190 & 1545 \\
\hline 458140 & INTEL CORP & 1973 & 1997 & 11521.0 & 1111.00 & 311 & 1365 \\
\hline 007903 & ADVANCED MICRO DEVICES & 1973 & 1997 & 2134.7 & 279.98 & 125 & 1082 \\
\hline 595112 & MICRON TECHNOLOGY INC & 1976 & 1997 & 1628.6 & 83.40 & 74 & 698 \\
\hline 918270 & VLSI TECHNOLOGY INC & 1982 & 1997 & 587.1 & 79.59 & 75 & 420 \\
\hline 032654 & ANALOG DEVICES & 1970 & 1997 & 773.5 & 106.87 & 63 & 377 \\
\hline 502161 & LSI LOGIC CORP & 1982 & 1997 & 901.8 & 98.98 & 74 & 302 \\
\hline 460254 & INTL RECTIFIER CORP & 1965 & 1997 & 328.9 & 16.38 & 13 & 169 \\
\hline 235204 & DALLAS SEMICONDUCTOR CORP & 1984 & 1997 & 181.4 & 22.65 & 13 & 165 \\
\hline 122574 & BURR-BROWN CORP & 1975 & 1997 & 194.2 & 21.85 & 1 & 141 \\
\hline 827079 & SILICONIX INC & 1975 & 1997 & 196.5 & 15.78 & 16 & 114 \\
\hline 983919 & XILINX INC & 1984 & 1997 & 355.1 & 45.32 & 32 & 96 \\
\hline 020753 & ALPHA INDS & 1967 & 1997 & 78.3 & 3.26 & 2 & 91 \\
\hline 021441 & ALTERA CORP & 1984 & 1997 & 198.8 & 45.99 & 19 & 91 \\
\hline 989524 & ZILOG INC & 1972 & 1997 & 223.3 & 23.05 & 11 & 89 \\
\hline 535678 & LINEAR TECHNOLOGY CORP & 1976 & 1997 & 200.5 & 18.39 & 7 & 80 \\
\hline 232806 & CYPRESS SEMICONDUCTOR CORP & 1984 & 1997 & 406.4 & 53.19 & 25 & 75 \\
\hline 458118 & INTEGRATED DEVICE TECH INC & 1982 & 1997 & 422.2 & 78.38 & 13 & 73 \\
\hline 170021 & CHIPS \& TECHNOLOGIES INC & 1974 & 1997 & 73.4 & 11.79 & 4 & 67 \\
\hline 913283 & UNITRODE CORP & 1965 & 1997 & 97.1 & 9.43 & 7 & 64 \\
\hline 114577 & BROOKTREE CORP & 1984 & 1995 & 109.0 & 26.13 & 3 & 51 \\
\hline 049513 & ATMEL CORP & 1987 & 1997 & 375.1 & 43.03 & 8 & 48 \\
\hline 300645 & EXAR CORP & 1974 & 1997 & 159.5 & 14.38 & 3 & 40 \\
\hline 89674K & TRIQUINT SEMICONDUCTOR INC & 1984 & 1997 & 29.2 & 9.94 & 0 & 39 \\
\hline 232815 & CYRIX CORP & 1989 & 1996 & 246.1 & 24.75 & 10 & 38 \\
\hline 518415 & LATTICE SEMICONDUCTOR CORP & 1985 & 1997 & 144.1 & 22.86 & 1 & 34 \\
\hline $69344 \mathrm{~F}$ & SIERRA SEMICONDUCTOR CORP & 1986 & 1997 & 108.6 & 28.62 & 16 & 33 \\
\hline 984903 & XICOR INC & 1979 & 1997 & 103.4 & 14.09 & 1 & 32 \\
\hline 413136 & HARMON INDUSTRIES INC & 1974 & 1997 & 119.7 & 4.56 & 3 & 31 \\
\hline 103025 & BOWMAR INSTRUMENT CORP & 1971 & 1997 & 27.8 & 0.59 & 2 & 31 \\
\hline $57772 \mathrm{~K}$ & MAXIM INTEGRATED PRODUCTS & 1985 & 1997 & 153.9 & 22.56 & 8 & 30 \\
\hline 595017 & MICROCHIP TECHNOLOGY INC & 1987 & 1997 & 208.0 & 20.75 & 8 & 25 \\
\hline 815779 & SEEQ TECHNOLOGY INC & 1981 & 1997 & 21.5 & 3.28 & 1 & 24 \\
\hline 751907 & RAMTRON INTERNATIONAL CORP & 1989 & 1997 & 20.4 & 16.45 & 12 & 23 \\
\hline 527295 & LEVEL ONE COMMUNICATIONS INC & 1989 & 1997 & 46.8 & 9.96 & 4 & 22 \\
\hline 834256 & SOLITRON DEVICES INC & 1973 & 1996 & 6.3 & 0.00 & 0 & 20 \\
\hline 477178 & JETRONIC INDUSTRIES INC & 1967 & 1997 & 21.9 & 0.03 & 0 & 19 \\
\hline 594793 & MICREL INC & 1988 & 1997 & 35.9 & 3.79 & 5 & 19 \\
\hline 553649 & MSI ELECTRONICS INC & 1977 & 1997 & 1.1 & 0.11 & 0 & 17 \\
\hline 541402 & LOGIC DEVICES INC & 1976 & 1997 & 13.5 & 1.66 & 1 & 17 \\
\hline 00754E & ADVANCED PHOTONIX INC -CL A & 1985 & 1997 & 6.8 & 1.85 & 1 & 16 \\
\hline 909149 & UNIPHASE CORP & 1980 & 1997 & 32.9 & 3.06 & 3 & 16 \\
\hline 449693 & IMP INC & 1982 & 1997 & 59.8 & 7.19 & 3 & 15 \\
\hline 868532 & SUPERTEX INC & 1977 & 1997 & 31.8 & 4.43 & 0 & 14 \\
\hline 148881 & CATALYST SEMICONDUCTOR INC & 1988 & 1996 & 48.8 & 4.25 & 2 & 13 \\
\hline 928497 & VITESSE SEMICONDUCTOR CORP & 1988 & 1997 & 35.6 & 8.79 & 0 & 13 \\
\hline 254547 & DIONICS INC & 1973 & 1997 & 1.3 & 0.03 & 0 & 10 \\
\hline 007768 & AEROFLEX INC & 1974 & 1997 & 65.6 & 0.69 & 0 & 9 \\
\hline 01877H & ALLIANCE SEMICONDUCTOR CORP & 1992 & 1997 & 119.3 & 8.37 & 6 & 9 \\
\hline 594850 & MICRO LINEAR CORP & 1987 & 1997 & 41.7 & 9.21 & 3 & 9 \\
\hline 683960 & OPTI INC & 1991 & 1997 & 134.1 & 8.76 & 0 & 8 \\
\hline 404160 & HEI INC & 1977 & 1997 & 17.3 & 0.63 & 0 & 7 \\
\hline 829204 & SIMTEK CORP & 1984 & 1997 & 1.2 & 0.82 & 0 & 6 \\
\hline 595137 & MICROSEMI CORP & 1976 & 1997 & 119.2 & 0.92 & 1 & 5 \\
\hline 816629 & SEMICON INC & 1976 & 1997 & 6.7 & 0.20 & 0 & 5 \\
\hline 450909 & IBIS TECHNOLOGY INC & 1989 & 1997 & 3.2 & 1.24 & 1 & 5 \\
\hline 683815 & OPTEK TECHNOLOGY INC & 1981 & 1997 & 55.6 & 0.58 & 1 & 3 \\
\hline
\end{tabular}


Table A.1 (continued)

\begin{tabular}{|c|c|c|c|c|c|c|c|}
\hline CUSIP & Name of Firm & $\begin{array}{c}\text { First year } \\
\text { of data }\end{array}$ & $\begin{array}{l}\text { Last year } \\
\text { of data }\end{array}$ & \begin{tabular}{|c|} 
Sales in \\
$1994(\$ M)$ \\
\end{tabular} & $\begin{array}{c}\text { R\&D in } \\
1994(\$ M)\end{array}$ & \begin{tabular}{|l} 
Granted 1994 \\
Patent Apps.
\end{tabular} & $\begin{array}{c}\text { Total Patents } \\
\text { thru } 1996\end{array}$ \\
\hline $45811 \mathrm{~K}$ & INTEGRATED CIRCUIT SYSTEMS & 1985 & 1997 & 93.8 & 10.65 & 0 & 3 \\
\hline 594946 & MICROELECTRONIC PACKAGING & 1989 & 1997 & 42.4 & 1.73 & 0 & 2 \\
\hline 237887 & DATA SYSTEMS \& SOFTWARE INC & 1973 & 1997 & 79.7 & 2.91 & 0 & 2 \\
\hline 553477 & MRV COMMUNICATIONS INC & 1983 & 1997 & 17.5 & 2.14 & 0 & 0 \\
\hline 747277 & QLOGIC CORP & 1991 & 1997 & 57.7 & 7.60 & 0 & 2 \\
\hline 248719 & DENSE-PAC MICROSYSTEMS INC & 1984 & 1997 & 11.5 & 0.58 & 0 & 2 \\
\hline $88554 \mathrm{~L}$ & THREE-FIVE SYSTEMS INC & 1989 & 1997 & 85.5 & 1.27 & 0 & 1 \\
\hline 895919 & TRIDENT MICROSYSTEMS INC & 1992 & 1997 & 69.1 & 9.56 & 1 & 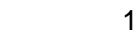 \\
\hline 449180 & HYTEK MICROSYSTEMS INC & 1982 & 1997 & 4.2 & 0.65 & 0 & \\
\hline $68556 \mathrm{E}$ & ORBIT SEMICONDUCTOR INC & 1993 & 1995 & 43.5 & 2.34 & 0 & 0 \\
\hline 595135 & MICROPAC INDUSTRIES INC & 1977 & 1997 & 9.4 & 0.32 & 0 & 0 \\
\hline 816850 & SEMTECH CORP & 1975 & 1997 & 25.8 & 0.88 & 0 & 0 \\
\hline 05548E & BKC SEMICONDUCTORS INC & 1991 & 1997 & 11.4 & 0.16 & 0 & 0 \\
\hline 989601 & ZING TECHNOLOGIES INC & 1985 & 1997 & 11.5 & 0.84 & 0 & \\
\hline
\end{tabular}

Notes to table:

Sales and R\&D are in millions of 1994 dollars.

Beginning and end years are for our dataset, not for the lifetime of the firm.

Granted patents in 1994 are the patents applied for in 1994 that have been granted by 1996

The patent total is all the patents granted to our firms that were applied for after the beginning year and granted by 1996 . 
Table A.2: Description of Firms in Interview Sample

\begin{tabular}{|c|c|c|c|c|c|c|}
\hline Type of Firm & Description & $\begin{array}{c}\text { Main type } \\
\text { of } \\
\text { Innovation }\end{array}$ & $\begin{array}{c}\text { \# firms } \\
\text { in } \\
\text { sample }\end{array}$ & $\begin{array}{c}\mathbf{1 9 9 6} \\
\text { Sales } \\
\text { (in \$m) }\end{array}$ & $\begin{array}{c}\text { US Patent } \\
\text { Portfolio (\# } \\
\text { patents issued, } \\
1975-96)\end{array}$ & $\begin{array}{c}\text { Growth in US patent } \\
\text { propensity, 1982-94 } \\
\text { (US patent apps/1992 } \\
\$ m \text { R\&D) }\end{array}$ \\
\hline Manufacturer & $\begin{array}{c}\text { Designs semiconductors, } \\
\text { and owns and operates } \\
\text { its own wafer fabrication } \\
\text { facility (fab) }\end{array}$ & $\begin{array}{c}\text { Process and } \\
\text { Product }\end{array}$ & 4 & $\begin{array}{c}\$ 1,200- \\
\$ 20,000\end{array}$ & $340-6500$ & $100 \%-300 \%$ \\
\hline Design Firm & $\begin{array}{c}\text { Designs semiconductors, } \\
\text { but subcontracts } \\
\text { manufacturing services } \\
\text { from other firms }\end{array}$ & Product & 3 & $\$ 30-\$ 500$ & $20-110$ & $-50 \%-233 \%$ \\
\hline
\end{tabular}


${ }^{1}$ The 1994 "Carnegie-Mellon" survey found that patents were a relatively ineffective way to capture returns from R\&D dollars to firms in all but a handful of industries (e.g., pharmaceuticals, chemicals and medical devices), which was consistent with earlier works in this field (Levin et al. 1987; Scherer 1959; Mansfield 1986).

${ }^{2}$ These surveys, their findings, and their methodologies are discussed in Section 2 of the paper.

${ }^{3}$ For example, the number of US patents that pertain to semiconductor devices and manufacture in 1994 was more than twice the number of patents issued in 1981 that belonged the same set of narrowlydefined semiconductor classes (USPTO, 1995). By contrast, the number of US patents issued in all classes in 1994 was only $50 \%$ greater than that issued in 1981. This disproportionate rise in semiconductor patents is similarly revealed in more recent years: the number of US patents issued that involved these semiconductor technologies rose by 34.5\% from 1990 to 1994, while the number of US patents issued as a whole rose by only $13.8 \%$ between these same years.

${ }^{4}$ The numbers in Figure 1 were compiled from several sources described in Section 4 below.

${ }^{5}$ See Hausman, Hall, and Griliches (1984) and Hall, Griliches, and Hausman (1986), also discussed in Section 4.

${ }^{6}$ In contrast, Kortum and Lerner examine the increase in patenting activity in particular classes (e.g., software and biotechnology) and then look at aggregate trends in R\&D intensity across the US and other national economies. As such, they can not control for whether the increased patenting activity in certain areas is simply due to a simultaneous increase in R\&D spending directed towards those areas (in which case, the propensity to patent in such areas has remained unchanged). Using a different approach, Cohen et al. (1997) construct a "patent propensity" measure based on the responses of firms to questions on the 1994 Carnegie-Mellon survey. As such, the authors are able to construct a useful estimate of firms' propensity to patent at one point in time, but are unable to explicitly track changes in this important variable over time for the firms in their survey.

${ }^{7}$ See Reinganum (1989) for a review of the patent races literature. O’Donoghue (1998) provides an overview of the more recent literature that examines the role of patents when innovation is cumulative.

${ }^{8}$ In our small sample of interviewed firms, some manufacturers also were "ramping up" their portfolios with the expectation that they would reap more direct benefits from these investments in the future. Most firms were well aware the billions in revenues earned by Texas Instruments from simply licensing rights to its vast patent portfolio.

${ }^{9}$ In contrast, Arora and Fosfuri (1998) assert that strong patent rights (in general) facilitated the creation of a "market for know-how exchange" between specialized engineering firms (SEFs) and large chemical manufacturers. An interesting distinction exists between the "specialized" firms examined by Arora and Fosfuri and the ones in our sample: unlike the SEFs, the firms in our study specialized in product, not process, innovation. As discussed below, the entry of the semiconductor design firms in our study was based on the adoption of a standard process used in semiconductor manufacturing and the ability of these firms to contract manufacturing services from so-called "foundry providers" (see Macher et al., 1998). Our interviews suggested that the primary importance of strong patent rights to these design firms was horizontal, not vertical, in nature: that is, strong patent rights appeared to be more important to these firms in staking out and defending their market share against other niche-market rivals than they were in managing their vertical contracts with manufacturing suppliers.

${ }^{10}$ The 1980 Supreme Court decision (Dawson Chemical Co. v. Rohm \& Haas, 448 U.S. 176, 221 ) ushered in a series of court rulings that were more favorable to patent owners. For example, in $S C M$ Corp v. Xerox Corp (645 F.2d 1195, 1206, 2d Cir. 1981), the District Court ruled that it was lawful to acquire patents, even if those rights were acquired with the intent of dominating a market should the products prove successful: "If the threat of treble damages liability for refusing to license were imbedded in the minds of potential patent holders as a likely prospect incident to every successful commercial exploitation of a patented invention, the efficacy of the economic incentive afforded by our patent system might be severely diminished."

${ }^{11}$ The 1984 National Cooperative Research Act reduced the antitrust penalties for collaboration among firms in "pre-commercial" research. In 1993, the NCRA was extended to cover joint production 
ventures.

12 "Mask work protection" is sui generis in that it is neither a patent law nor a copyright law, but combines features of both (Keustermans and Arckens, 1994: 10-3). Owners may register their mask works with the US Copyright office for a nominal fee (\$20 in 1994) in return for roughly 10 years of exclusive rights to reproduce, sell, and import semiconductors based on the layout design. Although this form of protection may protect against outright theft or unauthorized reproduction and use mask works, several changes over the past decade have undermined the effectiveness of this form of IP protection. Modern designs are so complex that low-cost copying of masks has become largely impractical (e.g., it is no longer possible to simply photocopy the layout design). Design tools also have become increasingly sophisticated, obviating the need to steal another firm's mask work (Lewis, 1995: p. 566).

${ }^{13}$ From the trust-busting era of the 1920-1930s through much of the 1970s, patents were largely viewed as anti-competitive weapons used by monopolists to stifle entry and to bar competition: "it was difficult to get a patent upheld in many federal circuit courts, and the circuits diverged widely both as to the doctrine and basic attitudes toward patents. As a consequence, industry downplayed the significance of patents" (Merges 1997: p. 12).

${ }^{14}$ Until 1982, twelve regional circuit courts had appellate jurisdiction over patent cases: "certain courts of appeals were believed to favor patentees, others were considered sympathetic to infringers. This gave rise to "forum shopping" — prelitigation strategies and gamesmanship_-directed to getting the litigation before a regional circuit court that would be most sympathetic to one's case" (Nies, 1993: p. 798).

${ }^{15}$ In 1984, the CAFC established that the challenger of patent validity must meet a "clear and convincing evidentiary standard," which increased the burden on challengers seeking to invalidate a

${ }^{16}$ Evidence on court rulings further demonstrates the importance of this 1982 reform: "between 1953 and 1978, circuit courts affirmed 62 percent of district court decisions holding patents to be valid and infringed and reversed 12 percent of the decisions holding patents to be invalid or not infringed. In the years 1982-90, the CAFC affirmed 90 percent of district court decisions holding patents to be valid and infringed and reversed 28 percent of the judgements of invalidity or noninfringement" (Lerner, 1995: p. 469; citing evidence from several sources).

${ }^{17}$ See, for example, Lerner (1995); Lanjouw and Schankerman (1997); Kortum and Lerner (1997); and Cohen et al. (1997).

${ }^{18}$ Economists have long analyzed the optimal design of the patent mechanism, emphasizing the tradeoff between creating incentives to conduct R\&D and the monopoly distortions associated with strong patents. See Reinganum (1989) for a review of this extensive literature. Early work in this field typically assumed that a patent provided firms a standalone technological "prize" over the resulting product or process invention; indeed, a concern was that firms would engage in socially wasteful "patent races" and conduct duplicative R\&D when patent rights were too strong. Recent studies have advanced the patentdesign literature by investigating the $\mathrm{R} \& \mathrm{D}$ incentives provided by patents when innovation is cumulative, rather than discrete, in nature (Scotchmer, 1991, 1996; Green and Scotchmer, 1995; Scotchmer and Green, 1990; O’Donoghue et al., 1998; and O’Donoghue, 1998).

${ }^{19}$ Patenting in the chemical-based industries is inherently better-defined, given the precision with which molecules can be specified, and products such as new drugs typically embody far fewer patented innovations than those embodied in a new semiconductor chip.

${ }^{20}$ More than one interviewee mentioned the "demonstration" effect of the Kodak-Polaroid decision on instant cameras. One pointed out that up until that time, infringing firms expected only to have to pay royalties on past use of the property covered by the infringed patent (a reasonable risk and slightly less expensive in an expected value sense than paying royalties in the beginning), whereas after Kodak-Polaroid firms perceived that they could be shut down with an injunction rather than simply paying the infringed firm.

${ }^{21}$ What Cohen et al. report is the average percentage of product or process innovations for which the appropriability mechanism is effective; we have turned them into ranks. The percentages for patents are 31 (product) and 25 (process). It is interesting that when we asked the patent counsel of a large 
semiconductor manufacturing firm for the same numbers, he gave 80 percent for both.

${ }^{22}$ Judging from the survey layout, the other 3 probably had not applied for patents for their R\&D unit during the past three years, so they skipped this section.

${ }^{23}$ In total, we met with representatives from 7 semiconductor firms between April 1998 and November 1998. In each case, we asked to meet with someone with direct responsibility for formulating and implementing the firm's patent strategy. Identifying relevant decision makers was straightforward for small firms: we typically met with someone with a legal/engineering background who was in charge of the firm's patenting activities; in one case, we met with the firm's CEO. For larger firms, we typically met with 2 or more persons, including in-house patent or corporate attorneys, patent licensing executives, or R\&D lab managers. In order to gain additional views on whether the firms in our sample are representative of industry-wide or cross-industry trends, we also met with attorneys who advise firms in the semiconductor and other industries on their use of patents in responding to litigation or in negotiating licensing agreements.

${ }^{24}$ In the semiconductor industry, manufacturing takes place in wafer fabrication facilities, or "fabs." Since the early 1980s, a wave of so-called "fabless" firms have entered the industry. These firms specialize in chip design and innovative products, and are "fabless" in the sense that they subcontract wafer fabrication services from other firms (Macher et al. 1998).

${ }^{25}$ Because of their pivotal roles in setting industry-wide norms in the patent and patent licensing arena, Texas Instruments and Intel were included in our interview sample. We are treating the names of the remaining firms as confidential, pending approval from interview participants.

${ }^{26}$ See, for example, Scherer et al. (1959), Mansfield (1986), Levin et al. (1987) and Cohen et al. (1997).

${ }^{27}$ As the licensing director of one firm noted, it takes roughly 5 years for a manufacturing method to become diffused throughout the industry. To the extent that billion-dollar fabrication facilities are based on that method, a process-related patent may be far more valuable to the firm in licensing income than the original products for which the process was developed. The cross-generational benefits of patents were also emphasized by an interviewee from a successful design firm. In this case, the design firm had asserted its patent rights based on prior-generation technology against a rival firm. In addition to the damages that the firm expects to receive, bringing the suit to trial was viewed as a strategic decision aimed at (1) making buyers more reluctant to purchase the rival's potentially-infringing products; and (2) diverting the rival's engineering and managerial efforts. In this case, the interviewee expected that the successful litigation over older technologies could improve his firm's chances of having its nextgeneration product adopted as the industry standard.

${ }^{28}$ See Barton and Parapatt (1998) for additional information on the Polaroid-Kodak dispute.

${ }^{29}$ A third "demonstration effect" was also widely noted, as implied by some of the examples discussed below. More specifically, several interviewees from manufacturing firms noted that top management in their firms redirected significant funds and resources into the patent department—but only the firm had faced direct losses as a consequence of patent infringement suits or had been unable to settle licensing or cross-licensing agreements on favorable terms. Interviewees from design firms also noted a general tendency of firms to "ramp up" patenting following their first patent-related lawsuit. Although the general environment of patent litigation is recognized by the firm, some noted that there is considerable uncertainty over when and whether the firm would face a detrimental suit itself. In the meantime, several interviewees noted a reluctance of top managers in their firms to redirect time and effort away from the engineering efforts on which the profits from the current generation of products are derived.

${ }^{30}$ Although not mentioned in our interviews, it is important to realize that the overall size of the semiconductor market had grown considerably during this period. For example, from 1980 to 1990 , worldwide semiconductor sales had increased from $\$ 13.6$ to $\$ 57.5$ billion (ICE Status Report, 1998). This growth in overall semiconductor sales may have heightened the incentives of some patent owners to seek sales-based royalties during this period.

${ }^{31}$ Several interviewees remarked that the most difficult negotiating position is against firms in unrelated industries that do not seek reciprocal exchange of technology and, more troublesome, 
independent inventors (such as Gilbert Hyatt or Jerome Lemelson) who have asserted their patents successfully in court and are only interested in a one-way transfer of royalty payments from the firm.

${ }^{32}$ Although some licensing agreements are negotiated using a list of the firm's "proud patents" (Grindley and Teece, 1997), according to the industry representatives with whom we met, firms occasionally find patents so difficult to value that some cross-licensing negotiations are conducted using patent counts as the unit of currency. Clearly, to the extent that this practice is widespread, there is a considerable incentive to apply for patents on minor innovations that have no other intrinsic value.

${ }^{33}$ A separate interview with a member of the board of a recent start-up firm highlighted the salience of these views. The design firm, which was established in 1994 and is still privately held, spends over $\$ 360,000$ a year on patenting, or almost $40 \%$ of its annual revenues. According to the board member interviewed, investors demanded that the firm acquire strong patent rights at an early stage in order to increase its leverage against future rivals and to reduce the likelihood that the small management and engineering team would become distracted with patent infringement suits brought against the firm.

${ }^{34}$ As discussed in the introduction, the obvious drawback to this approach is that it excludes "systems" manufacturers, such as AT\&T, Motorola, or IBM, that are important owners (and users) of semiconductor-related intellectual property but whose R\&D investments are broader in scope (e.g., directed towards telecommunications or computer technologies more generally). We excluded non-US firms (e.g., Hitachi or Samsung) for similar difficulties in obtaining reliable semiconductor R\&D investments for these firms; the patent propensities of non-US firms may also be driven by institutional factors of their home countries, which are beyond the scope of our study.

${ }^{35}$ See, for example, discussion in Hall, Jaffe, Trajtenberg (1998).

${ }^{36}$ We identified name changes and 1998 subsidiary information from Standard and Poor's "Corporate Descriptions Plus News" database available on Lexis-Nexis. Some firms were acquired or went bankrupt during the period of our study and were therefore not listed in current business directories. In this event, we retrieved the relevant information from the last available $10-\mathrm{K}$ filed by the firm. We identified 1994 and 1989 subsidiaries of large firms by using the Directory of Corporate Affiliations ("Who Owns Whom"); for smaller firms, we obtained the list of 1994 and 1989 subsidiaries from the list of subsidiaries (typically, Exhibit 21) filed with each firm's annual 10-K report. Finally, we identified all major mergers and acquisitions involving these firms from 1984 to 1998 using several databases and directories available on Lexis-Nexis, including: the Financial Times Mergers and Acquisitions Database, the IDD United States M\&A Transactions database, and the "news" portion of "Standard and Poor's Corporate Description Plus News" database.

${ }^{37}$ We used the business directories on Lexis-Nexis (discussed above) to identify the year in which each firm was established. To determine whether a firm was a manufacturer or not, we used 1997 industry data provided by Integrated Circuit Engineering, Inc. (ICE) in which a firm is classified as "fabless" if the majority of its wafers are manufactured by other parties. Because some of our firms had manufacturing capabilities at one time but had divested them by 1997, we supplemented these data by examining previous $10-\mathrm{Ks}$ for each firm.

${ }^{38}$ As discussed below, these data include information on these firms' successful patent applications (i.e., applications for which patents are eventually granted). Information on unsuccessful US patent applications (i.e., ones that do not result in issued US patents) is not publicly available in the United States.

${ }^{39}$ The ratio of the total number of successful patent applications in the sector to the total R\&D spending in the sector is plotted rather than the average of the patent- $R \& D$ ratios for each firm, to avoid the noise introduced by outlier observations with very small $R \& D$ programs. This procedure is equivalent to plotting a weighted patent-R\&D ratio where the weights are the size of the $R \& D$ program.

${ }^{40}$ In order to avoid confounding our patenting measure with the variable lags in processing in the US Patent and Trademark Office, we date our patents by the date of application, although we consider only patents that eventually issue. We have all patents that issue by 1997 , so our patent numbers are not quite complete in the later years. For this reason, we stop most of our analysis in 1994, because 1995 appears to be the first year in which truncation due to the issue lag is visible. 
${ }^{41}$ All the estimates in the paper were obtained using the POISSON procedure in TSP Version 4.5. See the TSP Reference Manual (1999) for details on the estimation strategy. The results have been benchmarked against published results in Cameron and Trivedi (1998).

${ }^{42}$ In addition to Pakes and Griliches (1981) and Hausman, Hall, and Griliches (1984), see Hall, Griliches, and Pakes 1986. For work that explores the econometric specification and estimation of this equation, see Garcia-Montalvo (1997) and Blundell, Griffith, and Windmeijer (1997).

${ }^{43}$ In fact, experimentation with lag structures using these data confirmed the results in the earlier literature, and also revealed that controlling for the age of these firms was sufficient to knock out any effects of R\&D spending prior to the year in which the patents were applied for.

${ }^{44}$ A new semiconductor fabrication plant now requires a capital investment of more than $\$ 1.5$ billion (ICE 1998).

${ }^{45}$ Ideally, we wish to test whether the patent propensities of the post- 82 entrant firms are greater than the patent propensities of entrant firms in the preceding period. We will explore whether we have enough observations with reliable R\&D data between 1975 and 1982 to make this more direct comparison.

${ }^{46}$ Unlike firms such as Intel or AMD that only sell semiconductors, Texas Instruments sells a broader range of electronic products (e.g., watches or calculators). However, TI is still primarily a semiconductor firm. According to TI's 1998 10-K report, semiconductor products comprised 83 percent of

${ }^{47}$ That is, $\gamma_{\mathrm{t}}-\gamma_{1980}$ is plotted.

${ }^{48}$ However, as we discussed earlier, there are some good reasons to think that patenting by small entrants may be a direct response to threats from incumbents, at least in this industry, which seems to us to be in the spirit of the regulatory capture hypothesis.

${ }^{49}$ Although the results are superficially similar for the entrant/incumbent and design/manufacturing split, in fact these splits do not do the same thing. Here is the two way table for the observations in our sample:

Number of Firm-Years per Group

\begin{tabular}{c|c|c}
\hline & $\begin{array}{c}\text { Manufacturing } \\
\text { Firms }\end{array}$ & Design Firms \\
\hline $\begin{array}{c}\text { Incumbent } \\
\text { Firms }\end{array}$ & 548 & 17 \\
\hline $\begin{array}{c}\text { Post-1982 } \\
\text { Entrants }\end{array}$ & 58 & 56 \\
\hline
\end{tabular}

${ }^{50}$ Controlling for changes in the quality of these firms' patent portfolios is important because it will enable us to test whether the recent surge in patenting reflects a rise in the R\&D productivity of these firms (in which case we would not expect a decline in quality), or whether the propensities of these firms to patent has simply risen over time (in which case we might expect the average quality of these firms' patents to decline).

${ }^{51}$ Indeed, the recent antitrust case brought against Intel Corporation by the Federal Trade Commission deals with precisely these issues, and may represent a swing of the pendulum in away from "pro-patent" US legal environment of the past two decades. More specially, the FTC filed an antitrust complaint against Intel in June 1998, claiming that Intel had denied three computer companies Compaq Computer, Digital Equipment, and Intergraph access to technical information they needed to develop computer systems based on Intel chips. A pivotal issue in the case is whether Intel had the right to refuse these companies licenses to key patents owned by Intel or whether Intel's intellectual property is an "essential facility" for these companies given Intel's dominance in the microprocessor market (See L.

The Financial Times, June 9, 1998: 1; and L. Kehoe, "Intel Rejects Monopoly Charges," The Financial Times, July 14, 1998: 4). 